University of Tennessee Health Science Center

UTHSC Digital Commons

\title{
Improving Literacy Through Instruction and Community Experiences: : The effect of a summer program on literacy outcomes of students from low Ses homes
}

Lisa DeLozier Bowers

University of Tennessee Health Science Center

Follow this and additional works at: https://dc.uthsc.edu/dissertations

Part of the Speech and Hearing Science Commons, and the Speech Pathology and Audiology Commons

\section{Recommended Citation}

Bowers, Lisa DeLozier , "Improving Literacy Through Instruction and Community Experiences: : The effect of a summer program on literacy outcomes of students from low Ses homes" (2012). Theses and Dissertations (ETD). Paper 29. http://dx.doi.org/10.21007/etd.cghs.2012.0033. 


\title{
Improving Literacy Through Instruction and Community Experiences: : The effect of a summer program on literacy outcomes of students from low Ses homes
}

\author{
Abstract \\ Among the academic challenges faced by students from low socio-economic (SES) homes is the loss of \\ academic skills during the summer months. Unfortunately, the public schools are often unable to provide \\ summer learning opportunities because limited space, funding, and teacher availability. Established \\ community organizations frequently provide summer programs, however, there is little research to \\ indicate that they can be used to address summer learning loss.
}

A summer program was designed to improve oral and written narrative skills for students from low SES homes. This program was based in a local community ministry and was designed to use thematic units that combined literacy activities with community experiences. Twenty-two students participated in the current study, with ages ranging from 7 years 8 months -11 years 7 months (mean age $=9$ years 2 months).

Based on prior research, it was predicted that the elementary school children from low SES homes who participated in this study would perform significantly lower on language and literacy assessments when compared to normative data. It was also predicted that these students would benefit from a summer literacy program focused on oral and written narratives and evidence significant improvements in narrative skills. It was also hypothesized that as a result of the summer program they would not evidence the expected summer learning loss of reading skills as measured by reading fluency and reading comprehension curriculum-based measures.

Testing prior to the beginning of the summer program showed that the participants obtained significantly lower scores on non-verbal intelligence, passage comprehension, narrative retell and vocabulary standardized assessments. However, students demonstrated decoding skills as measured by word identification and word attack assessments that were within normal limits. Therefore, language comprehension skills were the focus of the summer reading program.

The oral narrative samples gathered at the beginning and at the end of the summer program were scored using the Narrative Scoring Scheme (NSS) and compared to examine changes in both story grammar features (ex., characters, setting), as well as higher level narrative components (ex., cohesion). Written narrative samples were also collected at the onset and at the end of the program and analyzed for length (number of T-units and number of words), complexity (percentage of subordinate clauses) and number of unique vocabulary words. As a indicator of the summer learning loss of reading skills, oral reading fluency and retell fluency curriculum-based measures were obtained weekly from the students.

Results revealed a significant improvement in oral narrative skills and written composition. Students demonstrated a significant difference $(t=-2.280, p<.05)$ between preand post-program oral narrative samples, with scores improving from an average of 22 on the pre-program assessment to 25 on the postprogram assessment. Students also demonstrated significant improvements on written narrative samples. The total number of T-units increased from an average of 8.00 T-units at pre-program to $12.29 \mathrm{~T}$ units post-program. In addition, the average number of words per sample increased from 30 words the beginning of the program to 42 words at the end of the program. A significant difference was found for number of unique words per sample $(t=-3.199, p<.01)$, with students demonstrating an average increase of 12 unique vocabulary words in their writing. In addition, there was no significant change in the oral reading fluency and retell fluency measures, indicating that the students did experience a summer learning loss of literacy skills.

As the rate of poverty in the United States continues to grow, children from low SES homes will continue 
to challenge the educational system. To reduce 'summer learning loss', it is imperative to provide evidence-based programs for these students to maintain or facilitate gains in academic abilities during the summer months. Very few studies have examined how summer programs can be used to improve oral and written language skills for elementary school students, from low SES homes. This study demonstrated that a well-designed summer program at a local community center can improve narrative outcomes for students from low SES homes.

\section{Document Type}

Dissertation

Degree Name

Doctor of Philosophy (PhD)

\section{Program}

Speech and Hearing Science

\section{Research Advisor}

Ilsa Schwarz, Ph.D.

\section{Keywords}

literacy, narrative, poverty

\section{Subject Categories}

Communication Sciences and Disorders | Medicine and Health Sciences | Speech and Hearing Science | Speech Pathology and Audiology 
Improving Literacy through Instruction and Community Experiences: The Effect of a Summer Program on Literacy Outcomes of Students from Low SES Homes

\author{
A Dissertation \\ Presented for \\ The Graduate Studies Council \\ The University of Tennessee \\ Health Science Center
}

\author{
In Partial Fulfillment \\ Of the Requirements for the Degree \\ Doctor of Philosophy \\ From The University of Tennessee
}

By

Lisa DeLozier Bowers

August 2012 
Copyright (C) 2012 by Lisa DeLozier Bowers. All rights reserved. 


\section{DEDICATION}

I would like to dedicate this dissertation to those that have loved unconditionally.

To my Heavenly Father, I give thanks that you loved me from the beginning.

To my mom and dad in Delaware, thank you for laying the foundation of an early love for literature and a childhood filled with such enriching experiences.

To Carol, my kindred spirit. Thank you for your quiet strength and steadfast determination.

To my dad, my biggest fan. Thank you for the support and encouragement as I worked toward my goals.

To Andy, who found me along the way, took my hand and had faith that I would find the finish line. I love you. 


\section{ACKNOWLEDGEMENTS}

There are many people who contributed to this endeavor to whom I would like to give gratitude for their support, encouragement, and knowledge.

Thank you to Pamela, Ron and Max, without whom my work home would be upside-down and technologically challenged.

A special thank to Aunt June for the unlimited hours of editing, endless encouraging notes and support.

I would like to thank my friends and colleagues at SOAR Youth Ministries, Erica Wilson, Wilma Claiborne, and Franny Alexander. I am forever grateful for your support and friendship throughout the past four years. I am also grateful to the students at SOAR who participated in this study, whom I loved from day one.

Thank you to the undergraduate and graduate students that dedicated their summer to the students at SOAR and participated in hours of data transcription and analysis. You are a hard-working and delightful group and I wish you the best in your future endeavors as speech-language pathologists.

A special thanks to my classmates who were like family during graduate school, especially Hyejin Park, the Wilsons and the Martins. I am so thankful to have friends who were willing to listen to frustrations and fears as well as celebrate the triumphs and successes.

To Hyojin Yoon, my officemate and confident, I am so blessed to have been given such an amazing officemate and life long friend. You are a gift.

I would like to thank my Committee Members, Dr. Hedrick, Dr. Mills, and Dr. Wolbers. Dr. Hedrick, I have enjoyed our impromptu research discussions and sincerely appreciate your prayerful considerations. Dr. Mills, thank you for guiding my clinicallybased research with constructive and enthusiastic suggestions. To Kimberly, thank you for guiding me through the research process, awakening my heart for children who are deaf, and truly exemplifying the work-life balance I hope to sustain as an academic.

I would like to express my sincere gratitude to Dr. Ilsa Schwarz, for her always positive insight, both on research and life. Thank you for being a mentor, a cheerleader, a fabulous editor, and a friend. I hold you in the highest esteem and hope to follow the career path choices you have made as an accomplished scholar. 


\begin{abstract}
Among the academic challenges faced by students from low socio-economic (SES) homes is the loss of academic skills during the summer months. Unfortunately, the public schools are often unable to provide summer learning opportunities because limited space, funding, and teacher availability. Established community organizations frequently provide summer programs, however, there is little research to indicate that they can be used to address summer learning loss.
\end{abstract}

A summer program was designed to improve oral and written narrative skills for students from low SES homes. This program was based in a local community ministry and was designed to use thematic units that combined literacy activities with community experiences. Twenty-two students participated in the current study, with ages ranging from 7 years 8 months -11 years 7 months (mean age $=9$ years 2 months).

Based on prior research, it was predicted that the elementary school children from low SES homes who participated in this study would perform significantly lower on language and literacy assessments when compared to normative data. It was also predicted that these students would benefit from a summer literacy program focused on oral and written narratives and evidence significant improvements in narrative skills. It was also hypothesized that as a result of the summer program they would not evidence the expected summer learning loss of reading skills as measured by reading fluency and reading comprehension curriculum-based measures.

Testing prior to the beginning of the summer program showed that the participants obtained significantly lower scores on non-verbal intelligence, passage comprehension, narrative retell and vocabulary standardized assessments. However, students demonstrated decoding skills as measured by word identification and word attack assessments that were within normal limits. Therefore, language comprehension skills were the focus of the summer reading program.

The oral narrative samples gathered at the beginning and at the end of the summer program were scored using the Narrative Scoring Scheme (NSS) and compared to examine changes in both story grammar features (ex., characters, setting), as well as higher level narrative components (ex., cohesion). Written narrative samples were also collected at the onset and at the end of the program and analyzed for length (number of T-units and number of words), complexity (percentage of subordinate clauses) and number of unique vocabulary words. As a indicator of the summer learning loss of reading skills, oral reading fluency and retell fluency curriculum-based measures were obtained weekly from the students.

Results revealed a significant improvement in oral narrative skills and written composition. Students demonstrated a significant difference $(t=-2.280, p<.05)$ between pre- and post-program oral narrative samples, with scores improving from an average of 22 on the pre-program assessment to 25 on the post-program assessment. Students also 
demonstrated significant improvements on written narrative samples. The total number of T-units increased from an average of $8.00 \mathrm{~T}$-units at pre-program to $12.29 \mathrm{~T}$-units postprogram. In addition, the average number of words per sample increased from 30 words the beginning of the program to 42 words at the end of the program. A significant difference was found for number of unique words per sample $(t=-3.199, p<.01)$, with students demonstrating an average increase of 12 unique vocabulary words in their writing. In addition, there was no significant change in the oral reading fluency and retell fluency measures, indicating that the students did experience a summer learning loss of literacy skills.

As the rate of poverty in the United States continues to grow, children from low SES homes will continue to challenge the educational system. To reduce 'summer learning loss', it is imperative to provide evidence-based programs for these students to maintain or facilitate gains in academic abilities during the summer months. Very few studies have examined how summer programs can be used to improve oral and written language skills for elementary school students, from low SES homes. This study demonstrated that a well-designed summer program at a local community center can improve narrative outcomes for students from low SES homes. 


\section{TABLE OF CONTENTS}

CHAPTER 1. INTRODUCTION ...................................................................................1

Rationale for Present Study ................................................................................4

Purpose of the Present Study ..............................................................................4

Organization of Remaining Chapters .................................................................

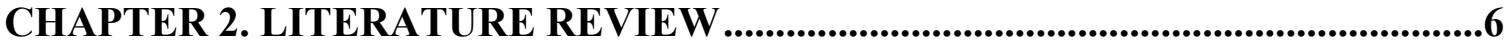

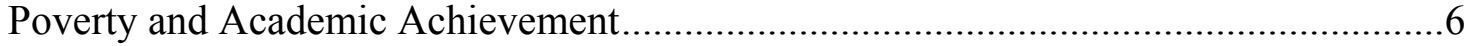

Summer Learning Loss and Summer School Programs ................................................

Literacy Skill Development ................................................................................

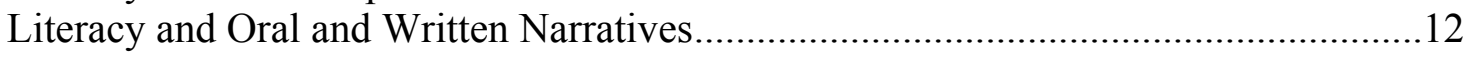

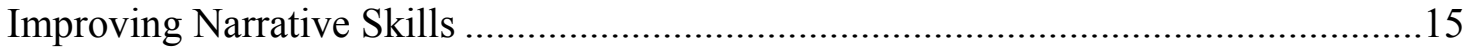

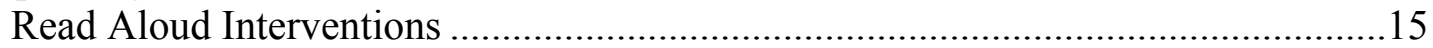

Teaching Narratives Using Visual Strategies .................................................... 17

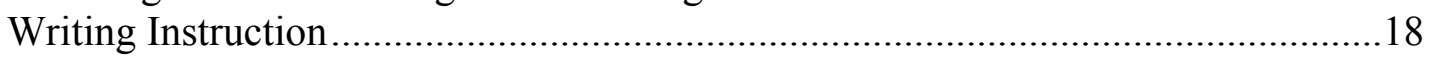

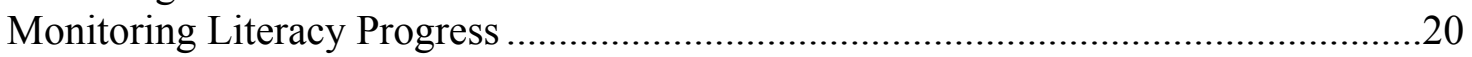

Literacy Instruction and Socio-Cultural Theories of Teaching .................................21

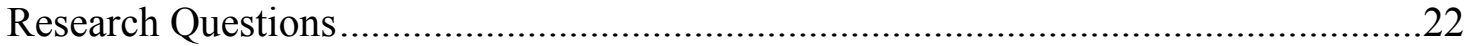

CHAPTER 3. METHODOLOGY ........................................................................23

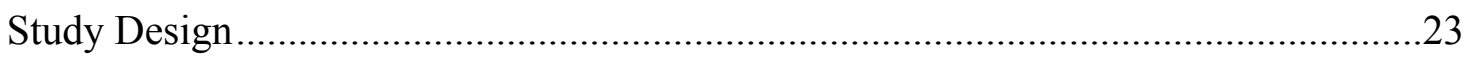

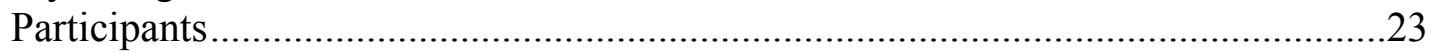

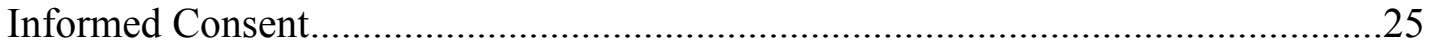

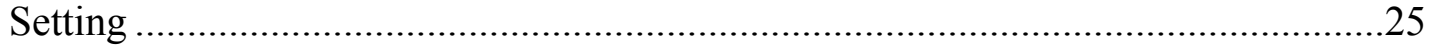

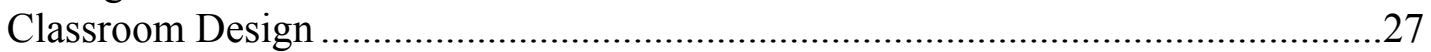

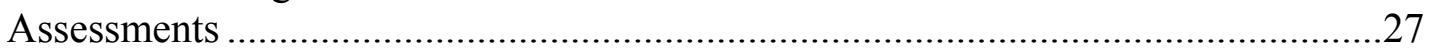

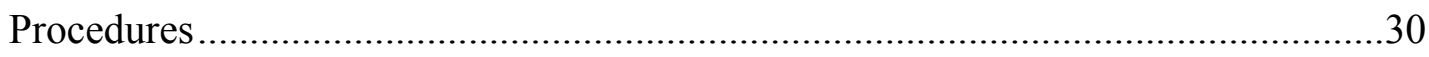

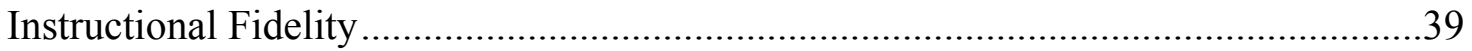

CHAPTER 4. RESULTS..........................................................................................40

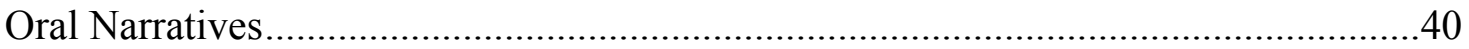

Assessment Prior to Program Initiation .............................................................40

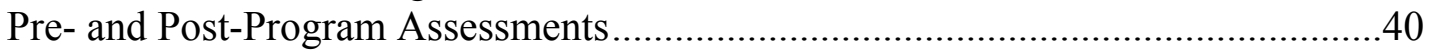

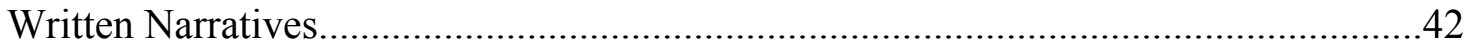

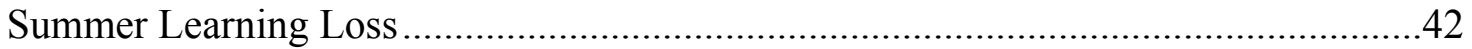

Results of Individual Goals and Objectives.......................................................45

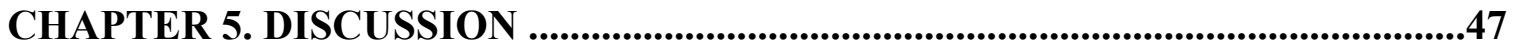

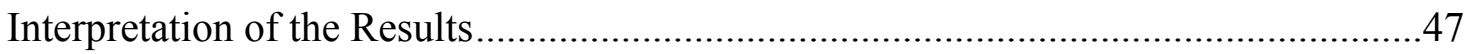

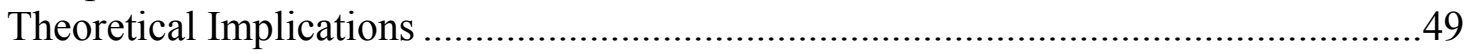

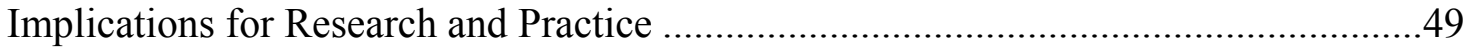

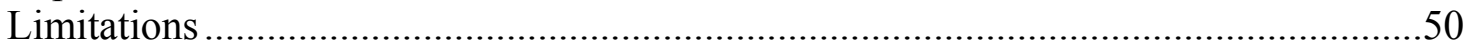

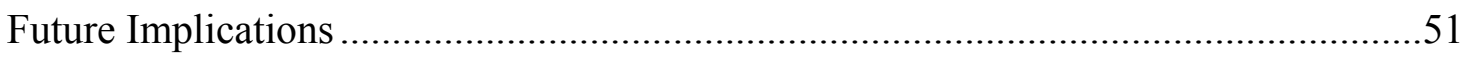


LIST OF REFERENCES .................................................................................................53

APPENDIX A. NARRATIVE SCORING SCHEME RUBRIC .....................................63

APPENDIX B. WRITING PROMPT AND INSTRUCTIONS ......................................65

APPENDIX C. WEEKLY THEMES AND CLASSROOM TEXTS ............................66

APPENDIX D. FIRST AND SECOND GRADE LESSON PLAN EXAMPLES.......67

APPENDIX E. THIRD AND FOURTH GRADE LESSON PLAN EXAMPLE .......68

APPENDIX F. FIFTH GRADE LESSON PLAN EXAMPLE ......................................69

APPENDIX G. WEEKLY WRITING LESSON PLAN EXAMPLE ..........................70

APPENDIX H. GRADUATE CLINICIAN WEEKLY LESSON PLAN

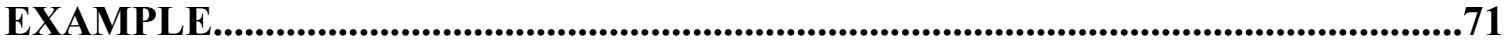

APPENDIX I. INDIVIDUAL RESULTS FOR STUDENTS' GOALS AND

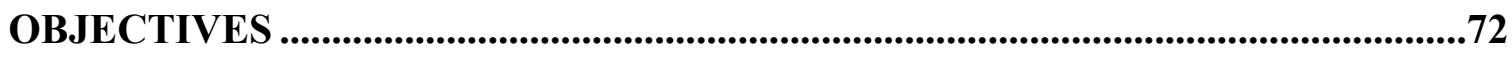

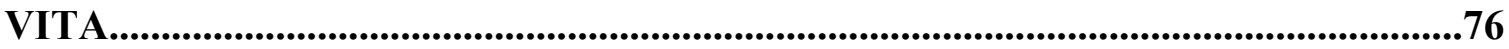




\section{LIST OF TABLES}

Table 1-1. Literacy benchmarks for fourth-grade students........................................2

Table 3-1. Means, standard error (SE), and ranges for standardized assessments .........24

Table 3-2. Pre- and post-assessment stimulus books ............................................29

Table 3-3. One-day literacy orientation schedule …...............................................

Table 3-4. Weekly thematic units and corresponding community experiences.............32

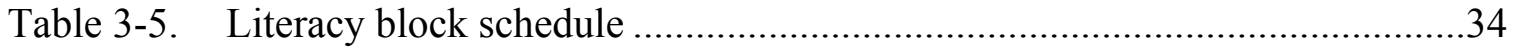

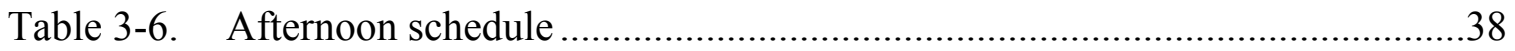

Table 4-1. Pre- and post-assessment scores of the Narrative Scoring Scheme ..............41

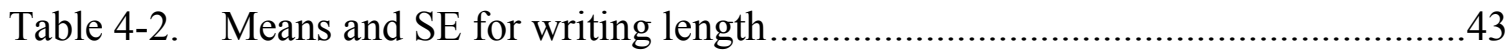

Table 4-3. Means and SE for total number of unique words ....................................43

Table 4-4. Retell Fluency (RTF) student means and range........................................45

Table A-1. Narrative Scoring Scheme rubric for A Boy, A Dog, and a Frog ................63

Table C-1. Weekly themes and classroom texts ....................................................66

Table I-1. Individual results for students' goals and objectives ..............................72 


\section{LIST OF FIGURES}

Figure 2-1. An illustration of spoken language components, literacy skills and the Simple View of Reading ...............................................................11

Figure 3-1. Standardized assessment scores and standard errors .................................26

Figure 4-1. Oral Retell Fluency (ORF) performance ..........................................44

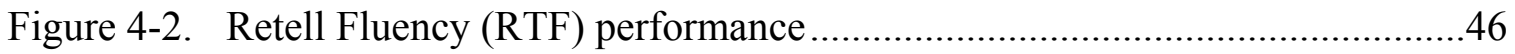




\section{CHAPTER 1. INTRODUCTION}

The United States has an information-driven economy, where employment opportunities are often dependent on the ability to process, manipulate and transmit knowledge (Apte, Karmarkar \& Nath, 2008). For this reason, our culture values a well educated populous and addresses this value through public education. It is expected that though the public education system, students will be given the opportunity to acquire the skills needed to obtain eventual employment (P.L. 103-227, Sec. 102). In particular, reading and writing skills are emphasized as they are critical to succeeding in an information economy.

To address the national need for a literate population, U.S. federal law requires that students receive high quality instruction in the educational system (No Child Left Behind; NCLB, 2002). Federal entities, such as the Department of Education, define benchmarks for academic "proficiency" so that states share outcome goals. Each state educational system is then responsible for providing students with quality educational opportunities to achieve these standards. Currently, state benchmark testing for reading and mathematics are the primary means used to determine academic proficiency (NCLB, 2002).

Although educational standards in the U.S. reflect the national sentiment that literacy is essential to success in our society, it is clear that a growing number of students do not meet state and national literacy benchmarks. Literacy benchmark testing results are based on a 0-500 scale, with scores below 203 deemed Below Basic, scores of 203237 considered Basic, 238-267 as Proficient and scores above 268 considered Advanced. Descriptions for all four proficiency levels for fourth grade students, including expected performance with narrative texts, are provided below (see Table 1-1). Based upon the most recent data available on literacy benchmarks from the National Assessment of Educational Progress (NAEP; Hemphill \& Vanneman, 2011), 34\% of fourth-grade students performed at a Basic level, 25\% performed at a Proficient level, and $8 \%$ performed at the Advanced level. Thus, $33 \%$ of fourth-grade students did not demonstrate the knowledge or skills required to establish partial mastery of grade level literacy skills.

The benchmark literacy scores for children raised in poverty are even more alarming than those for the population in general. A 2010 document published by the National Center for Educational Statistics (NCES; Aud et al., 2010) showed that the average literacy benchmark score for fourth-grade students from high-poverty schools was 202, considered Below Basic level. This low score is in contrast to the average score of 237 for fourth-graders from low-poverty schools, which is the high end of the Basic range. These averages highlight the marked differences between high poverty and low poverty schools. According to the 2010 report, only $45 \%$ of fourth-graders from high poverty schools demonstrated at or above the Basic level in reading, as compared to $83 \%$ of fourth-graders from low poverty schools. Statistics for proficient readers were no less discouraging, with only $14 \%$ of students from high poverty schools demonstrating at or above a Proficient level of reading, compared to $50 \%$ of students the same grade from 
Table 1-1. Literacy benchmarks for fourth-grade students

\begin{tabular}{ll}
\hline Literacy benchmarks & Description of 4th grade abilities \\
\hline Below Basic & $\begin{array}{l}\text { Students do not possess the skills required to perform at } \\
\text { the basic grade level. }\end{array}$ \\
Basic & $\begin{array}{l}\text { Students demonstrate partial mastery of proficient grade } \\
\text { level ability. Students can locate relevant information } \\
\text { from the text, make simple inferences. Students are able to } \\
\text { able to make simple inferences about characters, events, } \\
\text { plot, and setting, as well as identify the problem in a story. }\end{array}$ \\
& $\begin{array}{l}\text { Students can integrate and interpret texts, as well as apply } \\
\text { their understanding of the text to draw conclusions and } \\
\text { make evaluations. Students analyze character roles, }\end{array}$ \\
Proficient & actions, feelings, and motives. \\
& $\begin{array}{l}\text { Students can make complex inferences as well as apply } \\
\text { their understanding to make and support judgments } \\
\text { regarding text material. Students can identify story themes } \\
\text { and make complex inferences about characters' traits, } \\
\text { feelings, motivations, and actions. }\end{array}$ \\
\hline
\end{tabular}


low poverty schools. This report, as well as a growing body of evidence, suggests that a school's overall poverty level can affect its academic outcomes (Aud et al., 2010; Rumberger, 2007).

One particularly interesting fact regarding the education of students who attend high poverty schools or come from low socio-economic status (SES) homes, is the loss of academic skills during the summer months (Alexander, Entwisle \& Olson, 2007; Lee, Grigg \& Donahue, 2007). On average, students from low SES homes, particularly in the elementary school years, perform one to three months lower on academic assessments in the fall than when assessed for similar skills in the spring of the previous school year. In contrast, students from middle class homes typically demonstrate either no loss or an increase in academic ability (Burkham, Ready, Lee \& LoGerfo, 2004; Cooper, Nye, Charlton, Lindsay \& Greathouse, 1996). This achievement gap may be due to a variety of factors including: discrepancies between summer experiences, availability of books in the home environment, and limitations on the ability of children from low SES homes to take advantage of summer learning opportunities (e.g., summer camps, library trips).

Unlike the statistics on summer learning loss, the trajectory for academic gains during the school months are similar for students from all social classes (Farkas \& Beron, 2004). While during the academic year students from different SES backgrounds demonstrate comparable gains, research has shown that by the fourth grade, only $45 \%$ of students from low SES homes achieve at or above basic reading proficiency (Aud et al., 2010). The discrepancy between the reading proficiency scores of children from low and middle class homes can then, at least in part, be attributed to the loss of skills over the summer months.

Programs designed to improve literacy skills during the summer months have had measurable success. In a meta-analysis of summer programs conducted by Cooper, Charlton, Valentine and Muhlenbruck (2000), programs that specifically targeted reading reported positive gains for students; however, only six studies provided explicit descriptions of program content. Of these programs, the instructional approaches varied, as did the focus of the interventions (Tam, 1987; Welch \& Jensen, 1990). Overall, students that attended summer programs aimed at improving reading demonstrated significant gains in literacy; however, there was variability in the effect sizes among the different programs.

For many years, summer programs for neighborhood children have been provided by local community groups and church ministries (Barnes, 2008). Approximately 65\% of historically Black church congregations documented providing programs specifically geared toward the younger generation for the better part of the last century (Lincoln \& Mamiya, 1990; Mays \& Nicholson, 1933). Barnes (2008) described the wide variety of program types offered by these churches, including: Sunday School, Vacation Bible School, Boy Scouts and Girl Scouts, youth "at risk" programs, childcare, tutoring and athletics. Thomas, Quinn, Billingsley and Caudwell (1994) reported that of the church sponsored programs in the northeastern United States, $82 \%$ had working relationships with local schools. While a high percentage of church programs that indicated they had a 
cooperative relationship with local schools, the nature of this relationship was not described. Additionally, no information was provided regarding what types of academic services were being offered by these community programs. While there is potential for these community groups to provide opportunities to improve literacy skills, there is very little research on the efficacy of such programs.

\section{Rationale for Present Study}

According to the research by Cooper et al. (2000), summer learning loss may be prevented with well-designed summer programs; however, more information regarding the efficacy of supplemental academic programs coordinated by local community groups is needed. It is well-recognized that literacy is an area in which students from low SES homes demonstrate a learning loss during the summer months (Allington et al., 2010). As such, a summer literacy program located within a community-based organization may decrease summer literacy loss for students from low SES homes; however, there is currently insufficient research on such programs (Barnes, 2008). Thus, the efficacy of summer programs designed to improve literacy skills provided by local community groups and church ministries should be examined.

\section{Purpose of the Present Study}

A number of research studies have shown that students from low SES homes can benefit from programs provided during the summer months when school is not in session (Cirrin \& Gillam, 2008). Service delivery models outside of the public school setting should be explored to determine if other programs could prevent summer learning loss for students from low SES homes who are at risk of incurring a decline in academic abilities. Specifically, there is a need to determine if those skill deficits known to affect academic success can be addressed within the context of a community organization and outreach program (Grossman, Walker \& Raley, 2001). Therefore, a summer program at a community ministry was designed to improve oral narrative discourse and written narrative abilities for school-age children from low SES homes. The goal of the program was to reduce summer learning loss in the area of literacy. Specifically, it was predicted that narrative discourse intervention and interactive writing instruction provided in the context of varied community experiences could improve oral and written narrative outcomes and reduce summer learning loss in the areas of reading fluency and reading comprehension.

\section{Organization of Remaining Chapters}

There are four remaining chapters in this dissertation. Chapter 2 examines the literature pertaining to poverty and academic achievement, summer learning loss and summer school programs, literacy skill development, the importance of oral and written narratives to literacy acquisition, and methods known to improve narrative skills. 
Chapter 3 examines the methodology of this study and includes a description of the participants and setting, the data collection procedures, and methods for examining the data. Chapter 4 summarizes the findings of this study. Chapter 5 presents a summary of the study, conclusions and implications derived from the research findings, recommendations for practice based on the study and recommendations for future research. 


\section{CHAPTER 2. LITERATURE REVIEW}

\section{Poverty and Academic Achievement}

According to the National Center for Educational Statistics, (Aud et al., 2010) low SES level for a family is typically determined by using the national poverty level (i.e., at or below an income of $\$ 22,000$ ), parental education (high school graduation or less), as well as by enrollment in the government sponsored free or reduced-price lunch (FRPL) program (Harlwell, Maeda \& Lee, 2004). The overall poverty level for a school is typically measured using the percentage of students that are eligible for FRPL. When 76$100 \%$ of students are eligible for FRPL the school is considered "high-poverty", "middle poverty" when $26-75 \%$ of students are eligible for FRPL, and "low-poverty" when 0-25 $\%$ of enrolled students are eligible for FRPL (Aud et al., 2010). Using these guidelines, $20 \%$ of public elementary schools in the United States are considered "high poverty" schools (Aud et al., 2010).

The National Assessment of Educational Progress (NAEP; Hemphill \& Vanneman, 2011) examined the scores from high poverty and low poverty schools for a variety of different educational outcomes. Based on data collected from the 1998 - 2009 reading assessments, students in fourth-grade and eighth-grade from low poverty schools demonstrated significantly higher test scores than students from high poverty schools. Graduation and higher education statistics showed the same trends, with high poverty schools reporting a lower percentage of 12th-graders graduating with a high school diploma or attending college when compared to students from low poverty schools.

Research has shown that socio-economic status (SES) is not only associated with educational outcomes, but also the value families place on reading and writing (Perie, Grigg \& Donahue, 2005). Children from low SES homes, or "high poverty" homes, are considered to be at much greater risk of having difficulty learning to read than students from middle SES homes (Dickinson \& Snow, 1987). These differences may occur due to the strong relationship between their cultural beliefs, values and social practices and literacy within a child's individual family and community (Arnold, Lonigan, Whitehurst \& Epstein, 1994; Bus, 2003; Heath, 1983). Therefore, it is not surprising that pre-literacy skills and language abilities are related to social class (Farkas \& Beron, 2004; Hart \& Risley, 1995).

A seminal study by Hart and Risley (1995) examined the pre-literacy skills of children from different social classes. In this study, 42 children from three distinct social classes were observed from 10 months of age until 36 months of age. Children were grouped by SES levels: high SES homes in which parents were professors at a local university, working class homes, considered middle SES, and low SES homes with families who were on welfare. Family interactions were recorded for one hour each month in the home environment for two and a half years. Results revealed significant differences in the oral vocabulary skills of children across the three groups. These differences in oral vocabulary were observed between 14-18 months, very close to the 
time that children began to first verbalize words, with children in the high SES group verbalizing more than the low SES group. By 18-20 months, the children in the high SES group demonstrated increased vocabulary growth when compared to the other children, and by 24 months the vocabulary growth of both the high and middle SES groups significantly differed from the low SES group. By 36 months of age, the children from high SES homes were observed to produce twice as many vocabulary words as the children from low SES homes, and the children from middle SES homes were observed to use a vocabulary repertoire $50 \%$ larger than that of the children from low SES homes. Thus, we know that oral language differences between children from high SES and low SES exist and these differences start at an early age.

Another study that documented clear differences between children from different SES homes was conducted by Farkas and Beron (2004), using data collected by the Children of the National Longitudinal Survey of Youth (CNLSY). These data were collected from students over the course of a 14-year time period (1986 - 2000). Children ranging from three to fourteen years of age were tested using the Peabody Picture Vocabulary Test (PPVT, Dunn \& Dunn, 1997), which was administered several times per child at irregular intervals. For this study, parameters similar to Hart and Risley (1995) were used for identifying SES groups. Results revealed that children from low and high SES groups demonstrated significant differences in language abilities by the time they were three years of age, with those children from low SES homes having lower vocabulary scores. Vocabulary skills are known to serve as a foundation for reading; as such, this study is important as it demonstrates that students from different social classes begin school with very different vocabulary skills.

\section{Summer Learning Loss and Summer School Programs}

In general, students from low SES homes begin school with oral language and vocabulary skill deficits when compared to their middle class peers (Farkas \& Beron, 2004; Hart \& Risley, 1995). In addition, students from low SES homes are at great risk for experiencing what is known as the "summer learning loss" phenomenon (Alexander et al., 2007; Cooper et al., 2000; Lee et al., 2007). Summer learning loss refers to a significant decline in reading achievement during the summer months (Cooper et al., 1996; McGill-Franzen \& Allington, 2003). The book Summer Learning and the Effects of Schooling (Heyns, 1978), received national recognition as one of the first studies to document the relationship between SES and the loss of academic skills over the summer. Recent research reflects that this relationship has not changed and students from low SES continue to demonstrate a loss of academic skills during the summer months (Burkham et al., 2004; Cooper et al., 1996). Thus, the divide that exists from the onset of school between children from different social classes is exacerbated during the summer months when school is not in session.

Results from a meta-analysis conducted by Cooper and his colleagues (2000) revealed that differences in gender, race, or intelligence do not have an effect on rates of summer learning loss (i.e., reading and math skills); however, SES is a significant 
predictor for reading comprehension scores. Students from low SES homes demonstrate significantly lower reading comprehension scores when compared to students from middle-class homes (Cooper et al., 2000). There is no evidence that the gap between these two groups of students is dissipating (Perie et al., 2005); therefore, it is imperative to provide evidence-based summer programs for students from low SES to maintain and/or experience gains in academic abilities during the summer months.

To address the problem of summer learning loss for students from low SES homes, some schools offer summer programs (Cooper et al., 2000). Often, these programs fill quickly and can be limited by the school districts' available resources. Due to limited space, funding, and teacher availability, summer school programs are often restricted to admitting only those students who have failed classes, failed to be promoted to the next grade, or failed to pass required benchmark testing. As a result, students who are considered "at risk" may not be offered the chance to participate in a summer school program (Grossman et al., 2001). While federal spending has increased substantially in the last fifteen years to support additional school-based programs (U.S. Department of Treasury, 1999), there are still not enough programs available for all students that demonstrate learning loss during the summer months.

Educators have known for over 60 years that summer schools provide an opportunity for students with poor academic performance to improve their academic skills (Austin, Rogers \& Walbesser, 1972). A review of summer programs concluded that attending summer school led to moderate increases in elementary school students' achievement (Cooper et al., 2000). Overall, results revealed that summer programs that focused on remedial or accelerated learning had a positive impact on the knowledge and skills of participants. Because summer reading loss disproportionately affects students from low SES homes, summer programs may significantly increase outcomes for this population (Alexander et al., 2007; Cooper et al., 1996).

Research conducted on classroom instruction during the regular academic year indicates that more than any other single factor, students in classrooms with experienced teachers receive quality instruction and make the most academic gains (Allington \& Johnston, 2002; Pressley, Allington, Wharton-McDonald, Block \& Morrow, 2001; Snow, 2002). In the meta-analysis of studies pertaining to summer school programs from $1963-$ 1995, Cooper and colleagues (2000) noted that of the 41 programs designed specifically for "remediation of learning deficiencies" (pg. 45) all of the studies included experienced teachers. What is not clear at this time is what role highly qualified professionals must have for programs designed for students to maintain academic skills and not incur a summer learning loss (McGill-Franzen \& Allington, 2003). It has been proposed that using professional educators in a collaborative model with motivated interns or volunteers may provide a cost-effective approach for maintaining or improving literacy skills over the summer (Allington \& McGill-Franzen, 2009).

Speech Language Pathologists (SLPs) are professionals who provide services to students with a wide range of speech and language disorders, as well as to students who are in schools that use academic failure preventative models such as Response to 
Intervention (RTI, Montgomery, 2008). School - based SLPs are typically the first professionals within the special education department that interact with students who are 'at risk' of developing reading disabilities (Foster \& Miller, 2003). In addition, the academic and practical preparation of SLPs includes considerable work in addressing the skills needed to acquire literacy. For this reason, the scope of practice for school-based SLPs in recent years has placed an increased emphasis on reading and writing intervention for students with speech-language impairments, as well as the prevention of literacy deficits.

The participation of well-educated college or university students as tutors or reading instructors for children who have academic deficits is well documented in the literature. In a study by Lonigan, Anthony, Blooomfield, Dyer and Samwel (1999), trained undergraduates provided instruction examining the effect of reading interventions using narrative texts. Allor and McCathren (2004) had university education majors serve as teachers in order to provide a structured literacy-tutoring program. Pre-service teachers provided phonological awareness intervention for a study by Cobb (2001), and Pullen, Lane, and Monaghan (2004) demonstrated that children who participated in repeated readings with trained college students made significant gains in phonological awareness, sight word knowledge, and decoding. Collectively, these studies demonstrate the possibility of using college students, specifically those in the educational majors, to provide reading interventions for student at risk of failing reading.

At present, there is a need to explore the use of service delivery models and methods to help low SES students improve their academic abilities during the summer months. Local community centers, churches and ministries have historically served children during the summer (Lauer et al., 2006) and the participation of well-supervised college or university students may provide a low cost but effective means of providing instruction.

\section{Literacy Skill Development}

"Reading and writing float on a sea of talk" (Britton, 1970,pg. 164).

Literacy requires competence in listening and speaking (oral language), as well as reading and writing (written language) (van Kleeck, 2007). However, well before reading and writing skills are acquired, a typically developing child learns the listening and speaking skills that lay the foundation for literacy success. These skills include phonological awareness (Catts \& Kahmi, 2005), expressive and receptive vocabulary, knowledge of word order and word inflections (i.e., syntax and morphology) (Apel \& Thomas-Tate, 2009; Whitehurst, 1997), narrative discourse (e.g., Klecan-Aker \& Caraway, 1997; Snyder \& Downey, 1991) and world knowledge (Hirsch, 1987). In addition, children in literacy rich environments learn the social and cultural value of reading, known as "literacy socialization" (Van Kleeck \& Schuele, 1987, pg. 15). This early introduction to the importance of literacy has a positive effect on literary 
experiences and interactions for preschool children and facilitates the development of reading skills (Dickinson \& Smith, 1994; Van Kleeck \& Schuele, 1987).

While a variety of models for literacy development have been proposed, one of the most frequently cited is called the Simple View of Reading by Gough and Tunmer (1986). The Simple View of Reading model depicts an intricate relationship between the language comprehension and decoding skills needed for the development of reading comprehension. This theoretical framework explains how the successful acquisition of literacy skills, or the ability to understand written material, is achieved when increasingly automatic decoding skills are intertwined with expanding language abilities. Typically developing children establish the necessary language skills beginning at birth, and gradually develop the ability to understand and use language to communicate their ideas, thoughts, and feelings. Oral language skills along with literacy socialization provide the foundation children use as they enter school and begin the process of school-based literacy instruction.

Figure 2-1 represents the specific components of language that are important to reading in what is an adapted version of the Simple View of Reading (Gough \& Tunmer, 1986; Shaywitz, 2003). Components of spoken language are on the left of the model, including phonology, morphology, syntax, semantics and pragmatics. Decoding and language comprehension, the two constituents of the Simple View model, are to the right. Language skills children use that are associated with decoding abilities are in the center of the model, including print awareness, phonological processing skills, word attack and word identification. Language skills associated with comprehension are narrative discourse, story comprehension, world knowledge, inferencing and vocabulary. In addition, the concept of literacy socialization is also associated with reading comprehension. These components and skill sets influence a student's reading comprehension ability.

Decoding, or the ability to understand the orthography of a language, is based on the development of print awareness, phonological processing skills, word attack and single word reading. For the purposes of assessment, word attack constitutes breaking down a nonsense non-English word that follows the phonotactic rules of English into phonemic units and reconstructing these segments to form a word. For example, reading the word 'kib'. Word identification, or single word reading skills, is assessed using English words that a student may or may not know the meaning of but are able to pronounce. For example, reading the word 'scale'. Thus, a student may demonstrate proficient or even superior word identification and word attack skills with very little understanding of the words they are pronouncing.

At present, schools are spending a great deal of instructional time on decoding skills, such as phonics instruction (Berninger, Abbott, Billingsley \& Nagy, 2001; Snow, 2002), as encouraged by the National Reading Panel (NRP, 2000). Roth, Speece and Cooper (2002) found that phonological awareness skills measured in kindergarten predicted first- and second-grade word identification and word attack skills, this pointing to the importance of these skills. These findings were consistent with Adlof, Catts and 


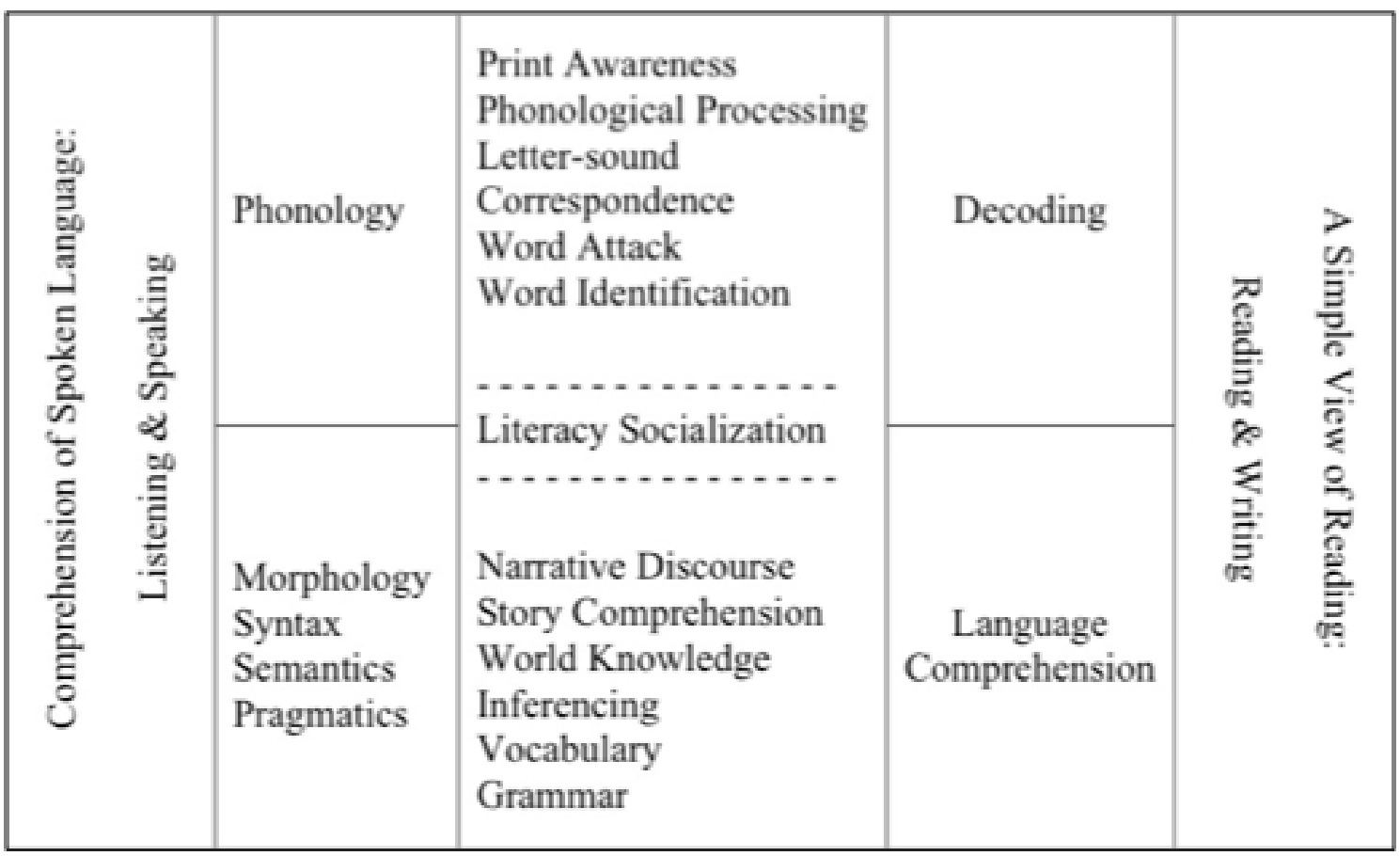

Figure 2-1. An illustration of spoken language components, literacy skills and the Simple View of Reading

Sources. Gough, P. \& Tunmer, W. (1986). Decoding, reading, and reading disability. Remedial and Special Education, 17(1), 6-10. Shaywitz, S. (2003). Overcoming dyslexia: A new and complete science-based program for reading problems at any level. New York: Knopf. 
Little's work (2006), which reported that for students in second-grade, decoding skills accounted for $35 \%$ of the unique variance in reading comprehension. Interestingly, listening comprehension only accounted for $4.9 \%$ of the unique variance for secondgrade students. This trend did not continue for older students, as fourth-grader's decoding abilities accounted for $18.8 \%$ of the unique variance for reading comprehension (a $16.2 \%$ decrease), and a $12.1 \%$ increase for the unique variance accounted for by listening comprehension ( $4.9 \%$ for second-grade and $17 \%$ for fourth-graders). For students in eighth-grade, listening comprehension accounted for $100 \%$ of the variance for reading comprehension. Therefore, while explicit teaching of decoding skills may initially increase fluent reading, it is not sufficient for achieving successful reading comprehension.

Language comprehension, in contrast to decoding, is a complex process that integrates semantics (i.e., vocabulary), morpho-syntax, narrative discourse, world knowledge and literacy socialization to understand and interpret text. Research indicates that these skills can predict later reading achievement (Catts, Fey, Tomblin \& Zhang, 2002; NICHD Early Child Care Research Network, 2005; Roth et al., 2002; Snow, 1991). For example, Catts and colleagues (2002) found that children who are diagnosed with a language impairment in kindergarten were at risk for reading disabilities in second and fourth grade. Additionally, grammar, vocabulary and narrative composites were significantly related to later reading outcomes. In agreement with these findings, Roth et al. (2002) reported that print awareness and semantic knowledge predicted first- and second-grade reading comprehension. Therefore, in order to improve reading comprehension skills, it is important to focus on language skills such as vocabulary so that children are able to learn to comprehend text.

Students with poor literacy or reading comprehension skills struggle to discern important information from their reading material (Myers \& Botting, 2008). Regrettably, many students from low literacy and low SES homes are considered "poor comprehenders", or students who demonstrate adequate decoding skills but below average comprehension (Catts \& Kahmi, 2005). It is apparent that there is a need to teach students to understand what they read. In order to treat these comprehension deficits, skill areas in the domain of language comprehension must be addressed.

\section{Literacy and Oral and Written Narratives}

Narrative discourse has been defined as "the ability to construct an original story and retell a recently heard story" (Storch \& Whitehurst, 2002, pg. 934). Oral narrative patterns and structures are ubiquitous across cultures and generations (Dimino, Taylor \& Gersten, 1995; Mandler \& Johnson, 1977). Flanagan (1992) stated that, "Evidence strongly suggests that people of all world cultures identify stories in some sort of narrative form. We are inveterate storytellers" (pg. 198). As such, independent of diverse cultural backgrounds, all children use narratives to interpret and retell fictional and autobiographical stories. Because of their presence across cultures, oral narratives can be 
used to improve the language comprehension skills necessary for literacy development (Davies et al., 2004; Norris \& Bruning, 1988).

Narrative discourse is significantly related to broader academic outcomes that include the ability to read and write (Heilmann, Miller \& Nockerts, 2010; Speece, Roth, Cooper \& De La Paz, 1999). Developmental research has shown that narrative discourse is learned through repeated exposure to print as well as exposure to story structure (Purcell-Gates, McIntyre \& Freppon, 1995) and that narrative discourse and literacy are integrated skills (Snow, 2002). Studies have also shown that understanding and producing oral and written narratives is important for reading comprehension (Myers \& Botting, 2008). For this reason, narrative instruction may positively influence reading comprehension (Davies, et al., 2004) and writing achievement (Englert \& Thomas, 1987).

Narrative discourse development provides a framework for discussing personal experiences, events, stories, and literature. Being able to construct oral and written narratives involves language comprehension and general knowledge of story structure (Curenton, 2004). Oral and written narratives often consist of predictable story elements including: setting, characters, internal responses, clear theme, correct sequence of events, and a resolution (Mandler \& Johnson, 1977; Stein \& Glenn, 1979). These story elements, which are also referred to as story grammar, provide the organization and structure for producing cohesive narratives (Montague, Maddux \& Dereshiwsky, 1990). Research shows that students typically develop the ability to construct narratives from listening to many stories and becoming familiar with experiences that involve predictable sequences (Mandler \& Johnson, 1977).

According to Hedberg and Westby (1993), there are five types of narratives. A script is a form of narrative that is used to express knowledge about a familiar event, often one that that occurs frequently. A recount narrative is when a student retells about a personal experience when prompted, while an account narrative is spontaneously given without a prompt. Typically, accounts and recounts are about events that are not shared by the listener. An event cast is used to explain an ongoing activity, reporting on a factual scene, or telling about a future plan. A fictional narrative includes past, present, or future events that did not or will not likely occur. Collectively, all of these narrative types utilize different information to present a clear and cohesive story to an intended audience.

Development of narrative structure has long been a topic of discussion (Applebee, 1978; Roth et al., 2002; Westby, 1991). Much of narrative development theory and clinical application stems from Applebee's (1978) six stages of narrative development. Stage one begins around two years of age when heaps, defined as a set of unrelated ideas and simple statements, emerge in a child's expressive language. By three years of age a typically developing child enters stage two, where children begin to link story elements such as a character, topic, and setting together. Stage three occurs around age four, when primitive narratives begin to emerge. These simple narratives include the same story elements as sequences, but also include a character's emotional state. By age four and a half, unfocused chains, or stage four, begin to emerge. These narratives include a sequence of events that are linked in a logical order, and may include a cause-effect 
relationship. By stage five, typically developing children are producing focused chains, which include a central character and a logical sequence of events. By stage six, children between the ages of six and seven demonstrate true narratives, defined as having a plot, character development, and full sequence of events. While adaptations have been made to Applebee's original six stages of narrative development, the general order of skill development is consistent in the literature (Hedburg \& Stoel-Gammon, 1986; HutsonNechkash, 2001; Klecan-Aker \& Kelty 1990; Westby, 1991).

Theories of narrative development suggest that students who have more experience with and exposure to stories will demonstrate greater oral and written narrative competence (Applebee, 1978; Bruner, 1986). Having a way to organize new information meaningfully (i.e., story structure) is often essential to understanding new material. As story grammar provides structure for narratives, story elements are concepts to which all students can relate and can use to express their own unique individual personal experiences, as well as use to understand narrative texts. Thus, oral narrative discourse can be used to discuss experiences, stories, literature, and their surrounding environments with students. The ability to write proficient narratives is equally important and is also linked to academic success (Nelson, Bahr \& Van Meter, 2004; Singer, 2007).

Klecan-Aker and Caraway (1997) studied the relationship between narrative skills and reading achievement with eighty African American students from the southeastern U.S. The participants included 46 fourth graders and 34 sixth graders. Using the parents' highest level of education, occupation, marital status, and sex (if a single parent home), the SES status of the students was reported to be middle class. Narrative skills and reading achievement were assessed using the Expression Connection (Klecan-Aker \& Brueggeman, 1991) and the Iowa Test of Basic Skills (ITBS; Hieronymus, Hoover \& Lindquist, 1986). The authors found that narrative skills significantly correlated with reading comprehension $(\mathrm{r}=.37)$. The relationship between narrative skills and reading achievement opens the potential for using narrative instruction as a method for enhancing learning that may transfer to other academic areas.

In a related study, Snyder and Downey (1991) investigated the relationship between word retrieval, phonological awareness, sentence completion, narrative discourse and reading achievement. Narrative discourse was defined as a student's ability to "use their knowledge of narrative structures to understand, recall, and infer information presented in stories" (pg. 132). Two groups of students ages eight to fourteen $(\mathrm{N}=186)$, 93 students with normal reading skills and 93 students with a diagnosed reading disability were matched for age, sex, and socio-economic status. Results demonstrated significant differences on word retrieval tasks, sentence completion tasks and narrative discourse abilities. Regression analyses of the data revealed group and age level differences for narrative discourse processing, suggesting that students with reading disabilities produced inferior narratives and that older students use narrative processing skills during reading tasks more than younger students.

Oral and written narrative skills have been examined with a variety of special populations, including children with specific language impairment (SLI) (Kaderavek \& 
Sulzby, 2000), children with learning disabilities (Arthaud \& Goracke, 2006; Dimino et al., 1995; Snow, 2002), language delays (Davies, Shanks \& Davies, 2004) hearing loss (Schirmer \& Bond, 1990), children diagnosed with autism (Capps, Lush \& Thurber, 2000), and English language learners (Gutiérrez-Clellen, 2002). These populations have demonstrated significantly lower oral and written narrative abilities when compared to typically developing students.

Studies of narrative skills with students from low SES homes have also been conducted (Storch \& Whitehurst, 2002; van Kleeck, Lange \& Schwarz, 2011; Whitehurst, 1997). In a recent example, van Kleeck and colleagues (2011) examined the results from the Renfrew Bus Story - North American Edition (RBS-NA; Glasgow \& Cowley, 1994) for 172 kindergarten students. Children were grouped by race (African American and European American children) and mothers educational level (high school or less and higher than high school). Raw scores for all four subtests of the assessment were examined, including information, sentence length, complexity and independence. Results revealed a significant effect for race $(\mathrm{P}<.01)$ and maternal education $(\mathrm{P}<.001)$ for the information subtest with no interaction, with race explaining $5.69 \%$ of the unique variance. European American children produced and average score of 22.79 on the information subtest while African American children produced an average score of 19.31. Thus, students from low SES homes demonstrate significantly lower narrative skills than students from middle class homes.

Overall, students with poor literacy abilities have also been shown to exhibit difficulty using effective language skills to produce narratives with a well-developed theme and structural cohesion of story elements (Norris \& Bruning, 1988). Therefore, understanding and producing narratives is an area that may require explicit instruction for many special populations, including students from low SES homes.

\section{Improving Narrative Skills}

Typically developing students acquire knowledge of narrative structure in a developmental progression; however, less proficient readers and writers often require explicit narrative instruction (Englert \& Thomas, 1987; Montague \& Graves, 1990). Research studies have demonstrated that there are a variety of strategies that may be used to improve oral narratives including read aloud interventions and the use of visual strategies. Written narrative skills may be improved by devoting time to writing centers and using interactive writing approaches to create texts for authentic audiences for an intended purpose. Each of these is described in detail below.

\section{Read Aloud Interventions}

Read-aloud interventions have been examined in several instructional formats, including: computer-assisted story reading (Verhallen, Bus \& de Jong, 2006), shared book experiences (Reutzel et al., 1994) and dialogic reading (Lonigan et al., 1999). 
Regardless of the treatment, students who participated in these various read-aloud interventions significantly outperformed students in control groups on measures of language and narrative skills (Lonigan et al., 1999; Reutzel et al., 1994; Verhallen et al., 2006).

A read aloud intervention conducted by Verhallen and colleagues (2006), examined unique ways to represent and interact with text, and focused on the use of computer-animated stories and their impact on oral narrative comprehension and language skills. Participants included sixty kindergarteners learning Dutch (the language of classroom instruction) as their second language. In addition, all students who participated in the study had been labeled "at risk" for academic failure by their teachers. A randomized design was used to place the students into four experimental conditions and one control condition. The story Winnie the Witch (Thomas \& Gorky, 1996) was used for all four experimental groups with differences in presentation (picture images vs. video) and frequency of story presentations (one presentation vs. four presentations). Prior to participating in the intervention, the student's level of text comprehension was tested by eliciting a narrative retelling from a book similar but unrelated to the intervention text. After the intervention, students were tested by eliciting a retelling of Winnie the Witch. The students were asked to retell this story twice, once prompted by the picture images and once with the video presentation with no sound. Results demonstrated that students in three of the four experimental groups, both video presentations of the storybook and the picture image group that received multiple presentations, demonstrated significant increases in story comprehension. The researchers concluded that repeated interactions with multimedia storybooks seem to provide increased understanding of narrative story structure and linguistic information.

Reutzel and colleagues (1994) examined the effects of two oral reading interventions, the Shared Book Experience (SBE, Holdaway, 1979), and the Oral Recitation Lesson (ORL, Hoffman, 1987) on narrative text retell and comprehension. While both of these instructional programs focus on oral reading as a method to improve students' overall reading growth, there are distinguishing differences between the instructional approaches of the two programs. The SBE intervention, derived from a whole language theoretical framework, focuses on developing story comprehension to facilitate meaning and improved responses to the narrative texts. The ORL approach, from interactive skills theory, considers reading accuracy, story grammar, fluency, and comprehension as distinct skills, where each skill set is segmented and receives individual focused attention. The goal of ORL is for students to demonstrate overall improved comprehension and fluency by working on skills sets individually.

To conduct the oral reading intervention study, seventy-nine second-grade students from two elementary schools were randomly placed into one of the two treatment groups, with 39 students assigned to the SBE group, and 40 students assigned to the ORL group. Students' reading development was measured over a four month period using a variety of assessments, including word analysis, story grammar comprehension, vocabulary, and fluency. Results revealed that students who participated in the SBE intervention demonstrated significantly greater improvement on word analysis 
and text comprehension measures. In addition, Reutzel et al. noted that using the Shared Book Experience supports the learning, understanding, and application of word analysis strategies and comprehension for students. For all other measures, including narrative retelling and story grammar comprehension, both groups performed similarly. Findings suggest that both interventions offer teachers viable oral reading instruction options for reading narrative or literary texts.

One study by Lonigan et al. (1999) examined the effects of two preschool reading interventions with children from low SES homes. This study used narrative texts that were taught using either: (1) dialogic reading (i.e., the child actively participates in the story telling) and (2) traditional shared reading activities (i.e., the adult reads and the child/student listens) as well as a no treatment control group. Ninety-five children, ages two to five years, were randomly placed in one of the three interventions. All children were given a battery of standardized assessments at the beginning of the study, including measures for oral language, listening comprehension, and phonological sensitivity. For both interventions, undergraduate volunteers read narrative storybooks to children in small groups using either dialogic reading or traditional reading activities. The same storybooks were used for both reading groups. Storybooks with narrative structures that included colorful illustrations and new vocabulary words were selected for the treatment conditions. Following the 6-week intervention, all children were assessed again, with positive results for both interventions. Thus, reading interventions for low SES participants that employ narrative texts using either a dialogic or traditional approach have the ability to improve language and pre-literacy outcomes.

\section{Teaching Narratives Using Visual Strategies}

One widely used strategy to improve a student's understanding of narrative structure uses visual representations of story grammar elements. Story mapping (Duke \& Pearson, 2002; Reutzel, 1984) is a strategy that identifies meaningful information within a story structure and organizes these concepts or events visually. Story mapping is a tool that can be used to facilitate improved understanding of how stories are constructed. Different types of story maps that can be used in the classroom include: outlines of story grammar elements, timelines that show events in the order that they occur in the story, or detailed pictures. Another visual strategy frequently described in the literature is story webbing (Arthaud \& Goracke, 2006). A story web represents the interconnected relationships of story elements or concepts (Griffin, Malone \& Kameenui, 1995) and resembles a web with the related elements represented on a string from the center of the 'web' where the main topic is located. Similarly, re-reading graphic organizers (Davis, 1994) may be used to familiarize students with the story text and structure prior to reading the entire text. After reading the text, students can also use visual strategies to reflect on the story and summarize material using story maps or other graphic organizers (Simmons, 1988).

Davis (1994) examined the effects of using a visual graphic organizer prior to reading instruction. Two different types of instructional methods were used, Direct 
Reading Activity (DRA) and a story mapping procedure conducted prior to reading. The DRA instructional method used a pre-reading intervention that consisted of developing background, creating interest in text, and establishing a purpose for the reading. The story grammar pre-reading instruction time included a visual representation of the story, or a story map, that students used during the reading process. Ninety students in third-grade and ninety students in fifth-grade participated in the study. Students from each grade were randomly placed in one of two groups: a control group that used two DRA prereading lessons, and an experimental group that used one DRA pre-reading lesson and one story grammar lesson.

Results from the Davis study showed that the experimental third-grade group performed significantly better on literal comprehension questions (62\% vs. 55\%) and inferential comprehension questions (60\% vs. $46 \%$ ) than the DRA control group. However, no significant differences were found between the control and experimental fifth-grade groups. It was hypothesized that the fifth-grade students demonstrated no significant gains because of developmental differences, and that older students do not need story structure instruction (Dreher \& Singer, 1987); however, other research has indicated fifth grade students do demonstrate improved comprehension using story grammar scaffolding techniques (Griffin et al., 1995; Reutzel, 1984). Davis concluded that using graphic organizers to introduce story grammar elements prior to introducing reading material for at least students in grade three may increase the amount of material that students understand and are able to retain.

\section{Writing Instruction}

Written expression as a means of learning, exploring, interpreting, analyzing, and synthesizing information is time consuming. Data from the National Department of Education's Writing Assessment (2002) show that students who reported participating in frequent writing assignments requiring at least a paragraph had the highest writing scores. Unfortunately, in traditional classrooms limited time is directed to students voicing their own opinions and creating expressive text through writing (Applebee, 2000). The National Study of Writing in the Secondary School (Applebee, 1984) investigated writing instruction in the school curriculum. Findings reported that while students spent $43 \%$ of time with "pencil to paper" (pg. 30), only 3\% of classroom time or homework assignments included creating original written expression. In other words, almost all writing in the classroom was spent answering stock questions, completing worksheet assignments, or writing short essays in which there was a predetermined correct answer. With such a limited amount of time dedicated to fostering independent writing skills, it is easy to see why high school students graduate with inadequate or only "basic" skills in writing.

While we know that a low percentage of classroom time is spent on writing instruction, Duke (2000) set out to determine if there were differences in the type of literacy opportunities offered to students from low SES homes when compared to students from middle class homes. Twenty first-grade classrooms, half from low SES 
schools and half high SES schools, were observed four times over the course of one academic school year. During each of the four on-site observations, data were collected regarding the classroom library resources and use, classroom print and text, and all activities during the school day that involved printed text. Specifically related to written language activities, Duke found significant differences between the proportions of classroom time spent on different experiences with text using writing activities. Low SES classrooms spent twice as much time on letter concepts $(6.8 \%)$ than high SES classrooms (3.4\%), and significantly more time on printing singular words (33.5\% compared to $28.1 \%$ ). Low SES classrooms also spent significantly less time on extended writing (34.8\% compared to $48.7 \%$ ). Thus, in low SES classrooms more time was devoted to rote drill activities than extended writing opportunities.

Despite an overall trend for classrooms to spend limited classroom time on written composition, particularly in low SES classrooms, writing process approaches have demonstrated success for the past thirty years (Flower \& Hayes, 1980). These approaches reinforce the importance of composition areas such as: topic selection, planning, organizing, drafting, revising, editing, and publishing. Strategic writing instruction furthers the development of writing skills for typically developing students as well as students who struggle with the process of writing composition (De La Paz \& Graham, 2002). Writing approaches that incorporate explicitly taught strategies with guided classroom writing activities have been successful with a number of populations, including students with learning disabilities (Montague \& Leavell, 1994), students who are deaf or hard of hearing (Wolbers, Dostal \& Bowers, 2012) and students from high poverty schools (Nelson, 2010).

Corden (2007) investigated the use of explicit writing instruction during one-hour writing workshops in class writing sessions with students between the ages of 7 and 11 years old. Eighteen teachers working in various school settings encouraged students working on sustained pieces of writing to create publishable works, use pre-planning strategies, write drafts and rewrite in response to constructive feedback. Results from this year long study suggested that planning and discussing writing with students had a positive impact on the quality of student's narrative writing.

Flower (1994) suggested that facilitating collaborative writing in authentic contexts is an effective way to develop writing composition. Strategic and Interactive Writing Instruction (SIWI; Wolbers, 2008) is an example of an instructional method that has students work collaboratively with guidance from a classroom teacher or speechlanguage pathologist to create a "publishable" work (e.g., class books, pamphlets, posters, essays, letters) intended for a specific audience (e.g., local church, congressmen, soldier stationed abroad, parents, school fair). SIWI uses a scaffolded approach during guided and shared writing that leads to the acquisition of writing skills that are then demonstrated in independent writing. Unlike typical class writing assignments, students are encouraged to interact and collaborate throughout the writing process, and there is an emphasis on exposure to and interaction with written text. SIWI has been shown to improve higher level (eg., cohesion) and lower level (eg., grammar) writing outcomes for 
personal narratives, including text structure, writing length, sentence complexity and sentence awareness (Wolbers, 2007; Wolbers et al., 2012).

The relationship between detailed explanation of the writing process and improved narrative writing (Pritchard \& Honeycutt, 2006) makes reinforcing the writing process an important aspect of writing interventions. Englert, Mariage and Dunsmore (2006) emphasized the use of visual scaffolds, such as the mnemonic POWER (PlanOrganize-Write-Edit-Revise), for improved writing outcomes. Visual scaffolds have been used with success in the general education classroom (Lorenz, Green \& Brown, 2009; Meyer, 1995) and with students with learning disabilities (James, Abbott, \& Greenwood, 2000), suggesting that providing a visual representation enhances the writing process for different groups of students. Providing visual scaffolds that students can refer to and utilize in the classroom during writing and writing discussions fosters learning of the writing process (Englert et al., 2006).

\section{Monitoring Literacy Progress}

How the summer learning loss phenomenon has been quantified, or measured, is highly variable. One challenge in documenting the loss of academic skills over summer lies in accounting for differences in the number of days a child must attend school, which varies by region. Also, exit testing and beginning of the year testing cannot be assumed to be given on the last day of the previous year, and the first day of the new year, thus the timing of test administration used to quantify changes in academic skills during the summer will also vary (Cooper et al., 1996).

The way that achievement is measured is also problematic because of the inconsistency in the types of test scores used. Some studies use absolute differences in raw scores or standardized scores to measure change in academic skills (Heyns, 1978; McCormick, 1981; Schacter \& Jo, 2005). Relative changes, usually determined by grade level equivalents, have also been employed (Entwistle \& Alexander, 1992; Pelavin, 1977). Regardless of whether raw scores, standardized scores, or grade equivalents are used, these scores are problematic. To assess summer learning, there is a relatively short time between norm-referenced test administrations. In most cases, the tests being used were not designed to be administered more than one time annually.

Over the past two decades, student assessment has been shifting to include tools that allow educators to quickly and efficiently assess performance and monitor progress on curricular items through frequently repeated administrations. These assessments are defined as curriculum-based measures (CBMs; Deno, 1985; Fuchs \& Fuchs, 1986; Shinn, Good, Knutson, Tilly \& Collins, 1992). CBMs provide an alternative or adjunct to normreferenced materials used to gain information pertaining to a child's present level of performance. CBMs are proven to be reliable and valid indicators of student knowledge and academic progress and have significant advantages over standardized instruments because they are brief, repeatable over a short time and sensitive to changes in knowledge (Hintze, Ryan \& Stoner, 2003; Shinn et al., 1992). 
Allinder Fuchs, Fuchs and Hamlett (1992) conducted one of the first studies that used CBMs as a way to monitor changes in academic abilities over the summer months. They examined the raw scores of second through fifth grade students' performance on spelling and math assessments. Two spelling and math measures were administered at the end of the academic year and the beginning of the subsequent academic year. The aggregated year-end and fall assessments were compared. Results revealed second and third grade students showed a significant loss of spelling skills and fourth and fifth grade students demonstrated a significant loss in math skills. However, for this particular study, no measures of reading fluency or comprehension were administered.

In a more recent study that used CBM's, Denton, Solari, Ciancio, Hecht and Swank (2010) conducted a summer intervention program that used both CBMs and standardized assessments for outcome measures. While standardized assessments were collected only prior to and directly after a four-week intervention period, CBMs were obtained throughout the intervention period, as they are designed to be given frequently to monitor change over time. The intervention was associated with improved outcomes on letter-word identification, oral comprehension, blending words, and the highfrequency words as measured by the CBM, while the control group was only observed to make significant gains on reading using the reading fluency measure. Therefore, for purposes of measuring reading fluency (decoding) and comprehension not only before and after a summer program, but during as well, CBM's provided a repeatable, reliable measure to document a change in reading abilities during a summer literacy program.

\section{Literacy Instruction and Socio-Cultural Theories of Teaching}

From a socio-cultural perspective, literacy instruction is often based on social interactions where individuals, culture, and activity are interrelated and together provide meaning (Englert et al., 2006, Hart \& Risley, 1995). Vygotsky (1978) proposed that language learning and development occur within social contexts. His theory of development describes not only a child's actual developmental level, but the level of potential development as well. He coined the term Zone of Proximal Development (ZPD), defined as "the distance between the actual developmental level as determined by independent problem solving and the level of potential development as determined through problem solving under adult guidance or in collaboration with more capable peers" (Vygotsky, 1978, p. 86). Thus, acquiring knowledge often occurs in collaboration with others. Learning strategies such as scaffolding and instructional supports that best facilitate learning are essential to Vygotsky's ZPD. His theory of development assumes that encouragement and guidance from a knowledgeable person can benefit students who are learning new material.

Wertsch (1991) extended the theoretical underpinnings of Vygotsky's work with what he termed mediated action, which describes "the essential link between cultural, historical, and institutional setting on the one hand and the mental functioning of the individual on the other" (p.48). Wertsch's work aimed to identify the complex relationship between language and the social context with which we interact with 
language his focus on action is an important one, as he views actions and experience in the context of social interactions as fundamental to learning experiences. Thus, language does not happen in spite of social contexts and experiences, but in the midst, and more to the point, because of these occurrences.

Research exploring Vygotsky's theory has shown that literacy activities and learning opportunities take place in social contexts and that participation in social reading and writing events can increase the reader's knowledge of oral and written language conventions (Snow \& Ninio, 1986). When the RAND Reading Study Group (RRSG, 2002) was asked to create a report to inform the U.S. Department of Education of the areas critical to reading comprehension, socio-cultural context was included as a component that interacts with three other central elements of reading. The RRSG defined reading comprehension as: "the process of simultaneously extracting and constructing meaning through interaction and involvement with written language. It consists of three elements: the reader, the text, and the activity or purpose for reading" (p. 11). Thus, the readers, the literacy items and the supplemental activities are all interdependent and occur in the context of their surrounding environment. The learning environment, selection of texts, and the variety of activities are all part of the student's learning experience.

In summary, we know that students from low SES homes demonstrate a summer learning loss of literacy skills (Alexander et al., 2007). To address this problem, a summer literacy program that involved a long-standing local community church program and focused on the improvement of oral and written narrative skills in a socio-cultural context was created. It was expected that a focus on oral and written narrative skills would not only improve narrative skills but also help to avoid the phenomenon of summer learning loss of literacy skills as measured through reading fluency and reading comprehension CBM's.

\section{Research Questions}

1. Do students, grades 1-5, from low SES homes who participated in a summer literacy program evidence improvements in oral narrative skills after a summer literacy program?

2. Do students, grades 1-5, from low SES homes who participated in a summer literacy program evidence improvements in written narrative skills after a summer literacy program?

3. Do students, grades 1-5, from low SES homes who participated in a summer literacy program evidence summer learning loss of literacy skills as measured by reading fluency and comprehension curriculum-based measures? 


\section{CHAPTER 3. METHODOLOGY}

\section{Study Design}

This study investigated the effectiveness of a summer literacy program designed to improve oral and written narrative skills and prevent summer learning loss in the area of reading for students from low SES homes. A quasi-experimental within subjects design was used to demonstrate progress on four dependent variables: oral narrative skills, written narrative skills, reading fluency and reading comprehension.

\section{Participants}

Twenty-two elementary school students participated in the current study. The mean age of the students at the start of the study was 9 years 2 months (range 7 years 8 months - 11 years 7 months). Ten students were in grades 1-2 (mean age: 8 years 10 months, range: 7 years 8 months - 9 years 6 months) nine students in grades 3-4 (mean age: 9 years, 10 months, range: 9 years 8 months - 10 years 4 months) and three students in grade 5 (mean age: 10 years, 11 months, range: 10 years 8 months -11 years 7 months). Twelve of the students were African American/black, nine students were of Hispanic/Latino ethnicity and one student was Caucasian/white. All students attended a single public school during the academic year in the Southeastern United States. The majority of students (over 75\%) attending this school receive free or reduced lunch, and all students live in an economically depressed area.

Approximately six weeks prior to the summer program, students were tested using a battery of diagnostic tools that included: the Test of Nonverbal Intelligence - 3rd Edition (TONI-3rd; Brown, Sherbenou \& Johnse, 1997), the Peabody Picture Vocabulary Test - 4th Edition (PPVT-4; Dunn \& Dunn, 2007), and the Woodcock Reading Mastery Test - Revised (WRMT-R; Woodcock, 1987) passage comprehension, word identification and word attack subtests. These assessments were given by ASHA certified speech-language pathologists (SLPs) or SLP graduate clinicians supervised by ASHA certified SLPs.

Students mean standard score (SS), standard error (SE), and range scores are listed in Table 3-1. On average, students demonstrated nonverbal intelligence scores within normal limits; however, the mean SS of 89.06 for these students was more than 10 points below the normative mean SS of 100. The WI and WA subtests from the WRMT$\mathrm{R}$ were used to assess decoding ability. The students performed at near average levels, with the mean SS for the WI subtest at 97.19 and the mean SS for the WA subtest at 98.44. For the PC subtest, students performed, on average, below the normative mean SS of 100 with a mean score of 88.06. This approached a standard deviation below the mean. Students' performance on the PPVT-4 demonstrated the lowest average of the assessment battery, with an average SS of 83.19 on the vocabulary test, which is more than one standard deviation below the SS mean of 100 . 
Table 3-1. Means, standard error (SE), and ranges for standardized assessments

\begin{tabular}{llll}
\hline Assessment & Mean & SE & Range \\
\hline TONI-3 & 89.06 & 3.01 & $75-124$ \\
WI & 97.19 & 3.02 & $73-115$ \\
WA & 98.44 & 3.45 & $75-125$ \\
PC & 88.06 & 3.08 & $69-107$ \\
PPVT- 4 & 83.19 & 2.7 & $64-105$ \\
\hline
\end{tabular}

Notes. TONI-3: Test of Nonverbal Intelligence, 3rd Edition; WI: Word Identification of the WMRT-R; WA: Word Identification of the WMRT-R; PC: Passage Comprehension of the WMRT-R; PPVT-4: Peabody Picture Vocabulary Test, 4th Edition. 
Figure 3-1 provides a visual representation of mean scores and standard errors for all standardized assessments. Independent one sample $t$-tests were used to compare the performance of the students to the standardization samples of the norm-referenced tests. Significant differences between students' performance and the standardized samples were found for the TONI-3 $(t=-3.630, p<.05)$, the PC subtest of the WRMT-R $(t=-3.874, p$ $<.001)$ and the PPVT-4 $(t=-6.222, p<.001)$. To measure the effect size of the differences for the TONI, PC subtest and PPVT-4, Cohen's $d$ statistic (Cohen, 1988) was calculated. Large effect sizes $(d=-.804, d=-1.286, d=-0.870)$ were found for all three assessments, respectively. No significant differences between the students from this study and the standardization sample were found for the WI and WA subtests of the WMRT-R.

\section{Informed Consent}

Informed consent materials were approved by the University of Tennessee Health Science Center Institutional Review Board (IRB). Consent forms were obtained from the students' legally authorized representative. Assent forms were obtained from participating interns and students ages 8-13 years. To protect the identities and personal information for all participants, data collected as part of this study were kept in either a locked cabinet or saved on a password-protected computer.

\section{Setting}

The summer program was held under the auspices of SOAR, an urban youth, nonprofit ministry that aims to provide an engaging environment for children that live in the surrounding area. During the academic year, students from high poverty homes in first grade through high school attend SOAR three days a week, starting directly after school until seven p.m. for tutoring, mentoring programs, healthy snacks and dinner, and extra curricular activities including: karate, dance, bible study, and choir. During the afterschool program, grade school classrooms at SOAR are divided by grade levels (1-2, 3-4, 5 ) and are assigned an "intern". Interns are typically local college students interested in education and inner city ministries. All interns receive training from the SOAR administrators for the after school program. Members from the community support these programs through garage sales, bake sales, golf outings, and $5 \mathrm{~K}$ races. SOAR also receives donations from local churches and community outreach programs.

All assessments and daily activities for this study took place at one location, the local program site. Population and demographics of the surrounding neighborhood are reported from 2006, the last published data available. In 2006, 98\% of the students were classified as being from disadvantaged homes. As defined by the U.S. government, these children are from families with an annual income below thresholds set according to family size; for example, a family of four living on less than $\$ 20,000$ per year. In 2006, population demographics for the school all of the children attend, as provided by the local school district, were as follows: 48\% African American, 28\% white, 20\% Hispanic, and 2\% Asian American. 


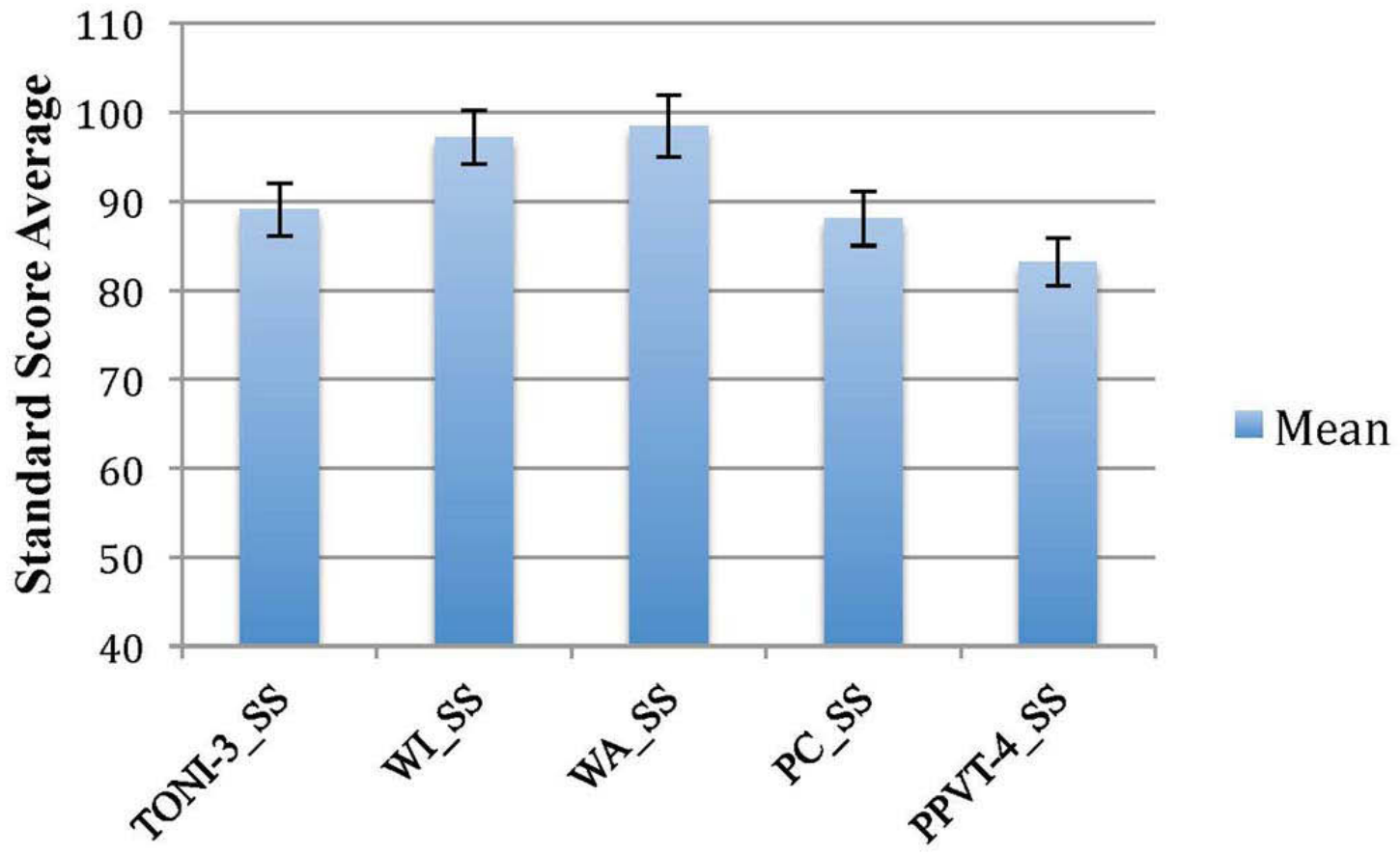

Figure 3-1. Standardized assessment scores and standard errors 


\section{Classroom Design}

The summer program included three classrooms, which were divided by grade levels based on the students last completed grade prior to this study: 1st-2nd grades, 3rd4th grades, and 5th grade. Each class was assigned an "intern", or a college student interested in working with children who live in an economically disadvantaged area. At the time of the study, all interns had completed at least two years of collegiate education. All interns had experience working with students in the regular after school program or inner city youth ministry experience, and all attended a weeklong training workshop prior to the summer program.

In addition to the program interns, five students in the University of Tennessee Health Science Center (UTHSC) graduate program in speech-language pathology provided individual and small group instruction. The graduate clinicians were assigned to students that demonstrated a significant deficiency based on standardized assessments (i.e., more than one standard deviation below the mean, or the bottom $30 \%$ of their classroom) in language and reading. There were four students per classroom designated for these services at the beginning of the program; however, due to attrition, final data were available for only a total of eight students. These included four students from the first-second grade classroom, two from the third-fourth grade classroom, and two from the fifth-grade classroom. The graduate clinicians were supervised by the primary researcher who is an ASHA certified speech-language pathologist. Each day, the graduate clinicians worked with their assigned students for thirty minutes throughout the summer program. The graduate clinicians worked on specific language goals that were consistent with the overall goal of increasing oral and written narrative expression, as well as grade appropriate state curriculum standards. The goals and objectives were written based on grade level standards. Data were collected on a weekly basis for each objective for each student working with the graduate clinicians.

\section{Assessments}

Oral narrative skills. Oral narrative skills were assessed three times, six weeks prior to the summer literacy program, at the onset and at the conclusion of the summer program. The Narrative Scoring Scheme (NSS; Miller \& Chapman, 2008), part of the Systematic Analysis of Language Transcription (SALT; Miller \& Chapman, 2008), was used to analyze narrative proficiency. The NSS is a standardized story retelling task that assesses retention of story grammar elements, as well as the ability to construct meaningful and cohesive narratives (Morrow, 1992). The NSS uses a rubric that combines both story grammar features (eg., characters, setting), as well as higher-level narrative components (eg., cohesion, using appropriate referents) to score a student's narrative ability (see Appendix A for a sample Frog rubric). The NSS is scored on a 0-5 scale, five for "proficient", three for "emerging" or "inconsistent" and one for "immature" or "minimal". 
Assessments prior to program. The oral narratives collected six weeks prior to the program were collected with the same books that were used to establish the normative data for the NSS so comparisons could be made. The stimuli books were administered by grade level, which included: 1st grade: Frog, Where are You? (Mayer, 1969), 2nd grade: Pookins Gets Her Way (Lester, 1987) 3rd grade: A Porcupine Named Fluffy (Lester, 1986), and 4th and 5th grade: Doctor De Soto (Steig, 1982).

Pre- and post-program assessments. The oral narratives collected at the beginning and end of the summer literacy program used two stories per grade. The books were from Mayer's Frog book series and were selected for their easily identifiable plot structure, setting, characters and clear theme. Stories were similar in number of pages, words and grade level vocabulary. See Table 3-2 for the books used for pre- and postprogram measures. For scoring purposes, rubrics similar to the pre-program Frog, Where are You? (Mayer, 1969) were used for all four additional Frog books.

Inter-rater reliability was determined using $20 \%$ of all the oral narratives. The narratives were independently scored by a trained graduate student and the researcher for reliability. The total point-to-point agreements were divided by the total number of possible items. Inter-rater reliability was $87 \%$ for story grammar components, which demonstrates a high level of agreement.

Written narratives. Written narrative samples were collected at the onset and conclusion of the literacy program. To obtain the written narratives, students were asked to write about a personal experience. A general prompt was given to all students (see Appendix B), but students were allowed the freedom to write about any topic. Personal written narrative samples were transcribed and analyzed using SALT software. Pre- and post-program narrative samples were divided into independent clauses and corresponding subordinate clauses, or T-units (Hunt, 1967) and analyzed for length (number of T-units and number of words), complexity (percentage of subordinate clauses) and number of unique vocabulary words.

Inter-rater reliability was determined using $20 \%$ of all the writing samples, which were independently scored by a trained graduate student and the researcher for reliability. Agreement for coding was calculated using Pearson product moment correlations. Interrater reliability was $96 \%$ for $\mathrm{T}$-units and $98 \%$ for subordinate clauses, which demonstrates a high level of agreement.

Reading fluency and reading comprehension. To assess for summer learning loss of critical literacy skills, reading fluency and reading comprehension were measured weekly using curriculum based measures (CBMs). Each week, students completed an oral reading fluency and corresponding retell task. The Oral Reading Fluency (ORF) and Retell Fluency (RTF), measures were selected from the Dynamic Indicators of Basic Early Literacy Skills (DIBELS; Good \& Kaminski, 2002). The ORF measure is standardized and designed to assess reading accuracy and fluency as well as monitor progress over time. Student performance is measured by having students read a passage aloud for one minute. Words self-corrected within three seconds are scored as accurate. 
Table 3-2. Pre- and post-assessment stimulus books

\begin{tabular}{lll}
\hline Grade & Pre Intervention & Post Intervention \\
\hline 1st - 2nd grade & A Boy a Dog and A Frog & One Frog Too Many \\
3rd - 4th grade & One Frog Too Many & A Boy, a Dog, a Frog and a Friend \\
5th grade & $\begin{array}{l}\text { A Boy, a Dog, a Frog and a } \\
\text { Friend }\end{array}$ & Frog Goes to Dinner \\
\hline
\end{tabular}


Words that are omitted, substituted, or hesitated on for more than three seconds are scored as errors. The oral reading fluency score is the number of correct words read per minute from the passage. The RTF was designed to provide a comprehension check for the ORF by monitoring those students that read fluently. Immediately after completing the ORF, the student is prompted to "retell what you just read about". Per the published instructions, the RTF measure is only administered to students who read 40 or more words per minute.

\section{Procedures}

Intern and graduate clinician orientation. Prior to starting the summer program a one-day orientation introduced the interns and graduate students to the program (see Table 3-3 for schedule). During the orientation, the daily schedule was reviewed. Each day included a literacy block in the morning and opportunities for community involvement in the afternoon. Oral and written language expression with an emphasis on narrative development was highlighted as the main goal for the overall summer program. The interns and graduate students were encouraged to create opportunities to engage students in literacy activities throughout the day. Sample classroom activities were explained, as well as modeled, by the researcher. Principles included: incorporating literacy as an integral part of the program, maximizing the use of previous experiences and background knowledge as the foundation for learning, and developing oral and written narrative skills as well as motivating students to participate in literacy activities.

In addition to the one day of literacy in-service, the interns participated in four pre-program training and preparation days that included information about: classroom management, overall expectations of behavior, discipline, and the daily schedule. Interns were also given time to work in their classrooms, purchase materials, and prepare for the summer program throughout the week prior to the start of the summer program.

Thematic units. From a socio-cultural perspective, situation-specific world knowledge can be utilized to guide students to construct meaning from personal experiences and connect information to written text (van Dijk \& Kintsch, 1983). For this reason, weekly thematic units were created for the program and chosen based on: (1) perceived student interest in material (2) cultural relevance for the students (3) access to community events with ties to the thematic units. See Table 3-4 for all weekly thematic units and corresponding community events.

Literacy materials for the thematic units were selected based on connections to planned community events and field trips, text level appropriateness and cultural relevance for the students participating in the program. During a morning literacy block, reading material was made available to students using multiple mediums including individual books for each student, power point presentations of books available on the computer, individual audio recordings of the book content, and student generated oral readings of text that were compiled into class audio books. This was done to allow for 
Table 3-3. One-day literacy orientation schedule

\begin{tabular}{|c|c|c|}
\hline Time & Materials & Task \\
\hline $\begin{array}{l}\text { 9:00 a.m. - } \\
\text { 9:30 a.m. }\end{array}$ & Weekly Schedule & $\begin{array}{l}\text { Overall schedule explained. Times for } \\
\text { literacy, lunch, and electives reviewed. } \\
\text { Expectations for class dismissal, } \\
\text { supervision, and restroom breaks given. }\end{array}$ \\
\hline $\begin{array}{l}\text { 9:30 a.m. - } \\
\text { 11:00 a.m. }\end{array}$ & $\begin{array}{l}\text { Curriculum \& } \\
\text { Lesson Plans }\end{array}$ & $\begin{array}{l}\text { Lesson plans reviewed. Interns given } \\
\text { time to learn the structure of class time } \\
\text { and discuss how activities will be tied to } \\
\text { class reading. Notebooks distributed } \\
\text { outlining literacy strategies (KWL, } \\
\text { scaffolding during reading, pre-reading } \\
\text { story maps, etc.) and reviewed. }\end{array}$ \\
\hline $\begin{array}{l}\text { 11:00 a.m. - } \\
\text { 12:00 p.m. }\end{array}$ & Writing Centers & $\begin{array}{l}\text { Writing center procedures reviewed. } \\
\text { Lesson plans distributed. }\end{array}$ \\
\hline $\begin{array}{l}\text { 12:00 p.m. - } \\
\text { 1:00 p.m. }\end{array}$ & LUNCH & \\
\hline $\begin{array}{l}\text { 1:00 p.m. - } \\
\text { 2:00 p.m. }\end{array}$ & Intern Notebooks & Instructional Fidelity measures reviewed. \\
\hline $\begin{array}{l}\text { 2:00 p.m. - } \\
\text { 4:00 p.m. }\end{array}$ & $\begin{array}{l}\text { Oral Narrative } \\
\text { Strategies }\end{array}$ & $\begin{array}{l}\text { Specific strategies reviewed. Sample } \\
\text { story maps completed. }\end{array}$ \\
\hline $\begin{array}{l}\text { 4:00 p.m. - } \\
\text { 5:00 p.m. }\end{array}$ & & $\begin{array}{l}\text { Interns, graduate clinicians and program } \\
\text { coordinators discussed any questions, } \\
\text { comments, or concerns. }\end{array}$ \\
\hline
\end{tabular}


Table 3-4. Weekly thematic units and corresponding community experiences

\begin{tabular}{|c|c|c|c|c|c|c|}
\hline $\begin{array}{l}\text { Community } \\
\text { Experiences }\end{array}$ & $\begin{array}{l}\text { Week } 1 \\
\text { Sports }\end{array}$ & $\begin{array}{l}\text { Week 2 } \\
\text { Animals }\end{array}$ & $\begin{array}{l}\text { Week 3 } \\
\text { Diversity }\end{array}$ & $\begin{array}{l}\text { Week } 4 \\
\text { Travel }\end{array}$ & $\begin{array}{l}\text { Week } 5 \\
\text { Vocations }\end{array}$ & $\begin{array}{l}\text { Week } 6 \\
\text { Service }\end{array}$ \\
\hline Monday & $\begin{array}{l}\text { Wee } \\
\text { Golf } \\
\text { Course }\end{array}$ & Petco & $\begin{array}{l}\text { African } \\
\text { Adventure }\end{array}$ & No SOAR & $\begin{array}{l}\text { Fire } \\
\text { Station }\end{array}$ & $\begin{array}{l}\text { Collect } \\
\text { Recycle }\end{array}$ \\
\hline Tuesday & $\begin{array}{l}\text { Wee } \\
\text { Golf } \\
\text { Course/ }\end{array}$ & $\begin{array}{l}\text { Discovery } \\
\text { Channel } \\
\text { Animal } \\
\text { Movie }\end{array}$ & $\begin{array}{l}\text { Worlds } \\
\text { Fair Park/ } \\
\text { Sunsphere }\end{array}$ & $\begin{array}{l}\text { Speaker - } \\
\text { Pilot }\end{array}$ & $\begin{array}{l}\text { Speaker - } \\
\text { TV } \\
\text { Anchor }\end{array}$ & $\begin{array}{l}\text { Recycle } \\
\text { Materials }\end{array}$ \\
\hline Wednesday & $\begin{array}{l}\text { Sports } \\
\text { Safety }\end{array}$ & $\begin{array}{l}\text { Zoo } \\
\text { Mobile to } \\
\text { SOAR }\end{array}$ & $\begin{array}{l}\text { Cooking } \\
\text { Classes }\end{array}$ & $\begin{array}{l}\text { Riverboat } \\
\text { Cruise }\end{array}$ & $\begin{array}{l}\text { Cooking } \\
\text { Classes }\end{array}$ & $\begin{array}{l}\text { Prepare } \\
\text { for Haiti } \\
\text { Fundraiser }\end{array}$ \\
\hline Thursday & $\begin{array}{l}\text { Smokies } \\
\text { Game }\end{array}$ & $\begin{array}{l}\text { Zoo } \\
\text { Fieldtrip }\end{array}$ & $\begin{array}{l}\text { ASL Sign } \\
\text { Workshop } \\
\& \text { Speaker }\end{array}$ & $\begin{array}{l}\text { Cooking } \\
\text { Classes }\end{array}$ & Trip to UT & $\begin{array}{l}\text { Block } \\
\text { Party } \\
\text { Fundraiser }\end{array}$ \\
\hline Friday & $\begin{array}{l}\text { SOAR } \\
\text { Baseball } \\
\text { Game \& } \\
\text { Swim }\end{array}$ & $\begin{array}{l}\text { Plays at } \\
\text { SOAR \& } \\
\text { Swim }\end{array}$ & $\begin{array}{l}\text { Plays at } \\
\text { SOAR \& } \\
\text { Swim }\end{array}$ & $\begin{array}{l}\text { Worlds } \\
\text { Fair at } \\
\text { SOAR }\end{array}$ & $\begin{array}{l}\text { Plays at } \\
\text { SOAR \& } \\
\text { Swim }\end{array}$ & $\begin{array}{l}\text { Lake } \\
\text { House }\end{array}$ \\
\hline
\end{tabular}


different types of interactions to be made with the same text material.

General classroom schedule. The summer program consisted of 29 days of instruction. The program followed the overall theme of "Oh, the Places You Will Go". This began with reading the Dr. Seuss book of the same title, and instructing students to place an emphasis on using prior experiences to interpret text, and to drive their curiosity to learn more. Each week had a specific theme that was the focus of the morning literacy block. The following is a general description of a typical day, with more specific information regarding each section of the literacy block provided in the next section. Each classroom used the thematic units and a book that was introduced and taught throughout the week. Following the morning literacy block (explained below), students were provided lunch by the ministry. Each afternoon, two hours of outside activities took place. While these activities were planned by the local ministry, they were closely related to the weekly theme to give students outside authentic experiences related to their reading topic.

Overall literacy block. The literacy block occurred from 9-11:30 a.m. each day (see Table 3-5). A classroom book was introduced, with each child having an individual copy of the text. Students participated in engaged reading for 30 minutes followed by a related activity. Children then participated in a writing center for 30 minutes. After the writing center activity, students were given time to read a book of their choosing from the library. They had the opportunity to read individually, with a partner, intern, or graduate clinician for 30 minutes. A library of over 3000 books, including groupings of books pertinent to the weekly themes, were made available to students. Many texts representing culturally and linguistically diverse populations were available to students, as well as books on $\mathrm{CD}$ and video.

Classroom book. Repeated interaction with stories is known to increase understanding of story structure (Verhallen et al., 2006), therefore, books were introduced in a variety of ways during the week. One book was featured in each classroom throughout the week ( $1 \mathrm{st}-2^{\text {nd }}$ grade) $\left(3 \mathrm{rd}-4^{\text {th }}\right.$ grade $)\left(5^{\text {th }}\right.$ grade $)$. Each day, the first 30 minutes of the literacy block focused on the classroom book that matched the weekly theme and was followed by a related activity for 20 minutes. For example, Night Golf (Miller, 1999) was the $1^{\text {st }}-2^{\text {nd }}$ grade classroom book for the sports thematic unit. See Appendix $\mathrm{C}$ for a complete list of weekly themes and classroom texts. The literacy block activities included: reading aloud to the class as a whole, reading in small groups, partner reading, individual reading, individualized tutoring. The activities focused on introducing key concepts, reviewing reading material, and actively engaging students in the literature via classroom discussions. Throughout the classroom book and related activity time, students were introduced to a variety of narrative types, including scripts, recounts, accounts, event casts and fictional narratives. Differences between the types of narratives were clearly explained.

In a large group activity, students worked on a classroom "What We KNOW, What We WANT to Know, What We LEARNED" chart (K-W-L). To use this chart, students were introduced to the weekly text and asked to first identify what they KNOW 
Table 3-5. Literacy block schedule

\begin{tabular}{ll}
\hline Time & Activity \\
\hline 9:00 a.m. - 9:30 a.m. & Classroom book \\
9:30 a.m. - 9:50 a.m. & Related activity \\
9:50 a.m. $-10: 20$ a.m. & Small group activity \\
10:20 a.m. $-10: 50$ a.m. & Writing centers \\
10:50 a.m. $-11: 20$ a.m. & Individual/paired reading \\
11:20 a.m. $-11: 30$ a.m. & Comprehension check \\
\hline
\end{tabular}


about the topic. For instance, for sports week, students were asked to identify vocabulary words they knew were related to baseball, if they had participated on a baseball team, and what rules they were already familiar with for the game. Then, they were asked to identify what they WANT to know about the subject or theme. Finally, during the week the students filled out what they had LEARNED about the topic. This time did not include non-related activities such as skill worksheets and phonics instruction.

Small group activities. Small group activities led by the classroom intern took place each day directly following the classroom book. Daily lesson plans that focused on specific language skills were created for each day for each class. All lesson plans focused on encouraging narrative discourse, reinforcement of story grammar and structure, and tied information from the classroom book to scheduled class field trips and events. An example of a lesson plan from each class is included (see Appendix D for 1st-2nd grade, Appendix E for 3rd-4th grade sample, and Appendix F for 5 th grade example). Below is a narrative describing sample classroom book and small group activities for one week.

Instruction across one week. Each week, one book was introduced to the students that matched the theme of the week. Below is a narrative of typical activities that occurred during the classroom book and related activity times (i.e., first 50 minutes of the literacy block).

Whole class book introduction: (Monday). Each Monday morning the intern introduced the focus book of the week. The class participated in a pre-story discussion that provided background knowledge and set a purpose for listening or reading. Students were asked to identify the author and illustrator. Other books by the same author were introduced as well. The "What We KNOW" and "What We WANT to Know" sections of the K-W-L were completed. The intern described the details of the beginning of the story, listed the key points of the story/chapter, and/or introduced key vocabulary words with visual pictures. Props, puppets, cutouts and felt board materials were used to support the story structure. Together, the students and classroom intern identified structural elements in the text (setting, plot, conflict/problem, resolution, theme), using a felt board, journals / notebooks, and a dry erase board to engage students in identifying these structures. After the story was read, students were asked to respond to questions that were literal (what happened?) interpretive (what did he mean by that?) and critical (what did they accomplish?) during oral and written activities. Pre-story maps were used to introduce story elements for students to use while reading the classroom book.

Whole class reading time: interaction with the book (Tuesday). Each Tuesday, the intern reviewed the book (or selection if the book was too long to complete in on day) that was introduced on Monday, asking questions such as "Who is the author?, Who is the illustrator?". As a class, students participated in rehearsing a play of the story. After scripts were finalized and reviewed, students picked parts from the play and began learning their parts. Students retold reading material that was previously covered on Monday. Information was added to the "What I LEARNED section" of the K-W-L 
classroom chart. Students volunteered to read sections of the book aloud. Story maps were reviewed.

Whole class reading: Direct listening strategy (Wednesday). On Wednesdays, the intern introduced the book in another format, usually on the computer, which was presented the content as a power point where the students changed the pages electronically and listened to the previously recorded text at their own speed in the computer lab. Questions regarding the book's content were asked in a dialog format between the intern and students. Conversations and questions that engaged the students were included, such as, "How does the story make you feel?" and "What was interesting? Funny? Sad?". Students were asked to create a different ending and asked, "If they could change part of the story, what would it be?". Students were encouraged to consider and compare story events with their own personal experiences. Students were asked to pretend they were a character from the book and describe what that felt like. Students would participate in continued practice for performance of the classroom play.

Whole class reading: Repeated reading (Thursday). Thursday mornings started with the intern reading the weekly book with the students following along. Purposeful mistakes like plot deviations or wrong vocabulary words were embedded for students to "catch" the intern's errors. The class discussed how they knew the intern was making errors in the reading. Students were then asked to describe their favorite part of the book. Students participated in continued practice for the classroom play performance. They were also encouraged to share books that they have found that week that are similar to the theme of the classroom book. An appropriate video that matched the story was shown with closed captions provided.

Whole class participation: Expression (Friday). Fridays were designed for the intern and students to collaboratively interact with the text. Students were encouraged to read, retell and interpret what happened in the story. A class play of the book was performed for students from other classrooms. Students were encouraged to be expressive, and audience participation was encouraged. Other expressive activities directly related to the text, such as musical stories or signing a visual representation of a story, were used.

Writing center. Students participated in structured writing time every day for 30 minutes. A writing center used a modified version of Strategic and Interactive Writing Instruction (SIWI) (Wolbers, 2008). SIWI is a writing approach that incorporates explicitly taught strategies with guided classroom writing activities. Students who are deaf or hard of hearing have used SIWI and made significant gains in written language skills, including improvements in length, complexity, and grammatical accuracy (Wolbers, 2007, 2008). While SIWI was originally designed to meet the specific needs of students who are deaf or hard of hearing, it was adapted to meet the needs of students with deficits in oral and written narrative skills. During SIWI, students worked with the classroom intern or speech-language pathologist to create a "publishable" work (e.g., class books, pamphlets, posters, essays, letters) intended for a specific audience (e.g., local church, congressmen, soldier stationed abroad, parents, school fair). Unlike typical 
class writing assignments, students were encouraged to interact and collaborate during all aspects of the writing process, and there was an emphasis on exposure to and interaction with written text.

During the summer program, students were encouraged to write based on their personal interests and experiences. Different types of writing were encouraged, including journal writing, letters, persuasive pieces, and narrative and expository writing. In all cases, an emphasis was placed on work that could be published for intended audience (e.g., parents, peers, community). A visual scaffold for writing, Plan-Organize-WriteEdit-Revise (POWER, Englert et al., 2006), was displayed in each classroom. The POWER posters provided a visual reminder that the interns would refer students to as they engaged in the writing process. Authentic pieces of writing were displayed, sent in the mail as appropriate, and "published" as literature to share with others.

A writing lesson plan and sample writing assignments were given to interns for each week (see Appendix G). For example, for the sports thematic unit, classrooms reviewed the rules of baseball during the week. Then, during the writing center time, they learned to write a letter, with the appropriate greetings and salutation and as a class created a sample thank you letter addressed to the Smokies baseball team for providing free tickets to a game. They included some of the new facts they had learned about baseball, as well as details about their experience at the game. After the class sample letter was finished, the students were then given time to write and decorate their individual thank-you letter. All letters were mailed to the local baseball organization.

Small group reading. Students were given time for small group reading every day. They were encouraged to read any book of their choosing from the program library. The library consisted of over 3000 book choices, encompassing a variety of genres and reading levels. One section of the library was organized by thematic units, so all of the books pertaining to the thematic units of the summer program (e.g., animals, travel, etc.) were grouped together regardless of ability level. All other books were color coded by grade level. While students were given freedom in choosing which books they wished to read, the classroom intern was able to monitor the level of selected books and offer assistance if the choice was too difficult for the student.

SLP graduate assistants worked with their assigned students during the small group reading time. All goals and objectives were based on diagnostic assessment results. Specific deficits in language were addressed, with an emphasis on oral and written narrative skills. Goals and objectives were in accordance with grade level expectations of the state of Tennessee curriculum standards. That is, state grade level standards were used to create student goals and objectives. See Appendix H for a sample weekly lesson plan.

Afternoon schedule: community experiences. After the literacy block, students participated in lunch, followed by "free choice" reading time and community experiences (see Table 3-6). During this time, interns were encouraged to tie experiences in the community back to literature reviewed during the literacy block. For some events, 
Table 3-6. Afternoon schedule

\begin{tabular}{ll}
\hline Time & Activity \\
\hline 11:30 a.m. $-12: 30$ p.m. & Lunch \\
12:30 p.m. $-1: 00$ p.m. & "Free Choice" Reading \\
1:00 p.m. - 3:00 p.m. & Community Experience \\
3:15 p.m. & Dismissal \\
\hline
\end{tabular}


graduate clinicians also participated in the afternoon activities to generalize objectives during afternoon activities. While no data were collected during this time, interns and graduate clinicians were encouraged to use "think alouds" and language building activities during the community experiences. Students were often asked after a community experience to "tell their story". Journal time in the classrooms was encouraged at the end of the day after field trips for students to write about their own experiences.

\section{Instructional Fidelity}

For treatment validity and replication purposes, as well as to provide evidence for the effectiveness of the intervention (Mowbray, Holter, Teague \& Bybee, 2002), fidelity of implementation of procedures was established. The extent to which interns followed the daily lesson plans was used as the treatment fidelity measure. One lesson plan was provided for each of the three classes for each of the 29 days of instruction. To determine instructional fidelity, the researcher observed the literacy block one time per week per classroom, tracking which lesson plan objectives were observed during the classroom instructional period. Interns were also required to hand in their lesson plans daily, checking off completed activities. Classroom observations and intern lesson plans were analyzed for fidelity purposes. A total of 102 objectives were reported as completed during the observed literacy block times. The researcher observed 96 of these objectives, with an overall agreement of $94 \%$. 


\section{CHAPTER 4. RESULTS}

The purpose of this study was to examine the effects of a summer literacy program designed to address oral and written narrative skills with students from low SES homes. It was anticipated that as a result of work on oral and written narratives, narrative skills would improve and summer learning loss would be reduced. The summer program was run by a local ministry that was not affiliated with the public school system although all the children attended the same public school during the academic year. A quasiexperimental mixed method study design was used to answer the research questions. This chapter will provide quantitative data regarding changes in oral and written narratives as well as data from reading fluency and reading comprehension curriculum-based measurements.

\section{Oral Narratives}

\section{Assessment Prior to Program Initiation}

Results from the students' oral narrative samples six weeks prior to the start of the study were compared to the oral narrative samples analyzed using the NSS for children ranging from 7 years 4 months to 10 years of age in the SALT database. On average, the students from the low SES homes received a NSS score of 17.27. Samples from the NSS database rendered an average score of 23.38 with a standard deviation (SD) of 4.32. Results from an independent one sample $t$-test revealed a significant difference between scores on the NSS for the students participating in this study and those from the NSS normative sample $(t=-2.75, p<.05)$. To measure the effect size of the differences, Cohen's $d$ was calculated. A large effect size was found for differences between the NSS scores of the two groups $(d=-0.682)$.

\section{Pre- and Post-Program Assessments}

Using a within subjects design, the oral narratives collected at the onset and conclusion of the literacy program were compared using a paired sample $t$-test to examine changes in oral narrative abilities. There was a significant difference $(t=-2.280$, $p<.05)$ between the pre- and post-program oral narrative samples. On average, students scored a 22 on the pre-program assessment and a 25 on the post-program assessment.

Means and standard error calculations for the overall narrative scores as well as the individual narrative categories are listed in Table 4-1. Significant differences were noted for the sub-categories of character development $(t=-3.235, p<.01)$ and referencing $(t=-3.205, p<.01)$. On average, students demonstrated an increase in identifying characters of the story and using referents appropriately from pre- to postprogram assessment. 
Table 4-1. Pre- and post-assessment scores of the Narrative Scoring Scheme

\begin{tabular}{lccccc}
\hline \multirow{2}{*}{ Assessment } & \multicolumn{2}{c}{ Pre-Assessment } & & \multicolumn{2}{c}{ Post-Assessment } \\
\cline { 2 - 3 } \cline { 5 - 6 } & Mean & SE & & Mean & SE \\
\hline Narrative & 22.07 & 1.07 & & $25.00^{*}$ & 1.06 \\
Introduction & 3.0 & .20 & & 3.55 & .21 \\
Characters & 3.25 & .21 & & $4.02^{*}$ & .16 \\
Mental State & 3.20 & .20 & & 3.23 & .26 \\
Referencing & 2.95 & .20 & & $3.66^{*}$ & .21 \\
Conflict & 3.34 & .24 & & 3.34 & .24 \\
Cohesion & 2.98 & .21 & & 3.55 & .17 \\
Conclusion & 3.30 & .19 & & 3.57 & .22 \\
\hline
\end{tabular}

Notes. * Significant at the $\mathrm{p}<.05$ 


\section{Written Narratives}

Personal written narrative samples were collected from fifteen students prior to and at the completion of the summer literacy program. While data were collected for twenty-two students at the beginning of the program, three students were not able to write a personal narrative sample, and four were absent when the post-program writing samples were collected. Writing length was assessed using the total number of T-units and the total number of words in a sample. The mean and standard error for both total T-units and total words are displayed in Table 4-2. Results of the paired sample $t$-test demonstrated a statistically significant difference for both total number of T-units $(t=-3.665, p<.01)$ and total number of words $(t=-3.336 p<.01)$. From pre- to post-program assessments, students demonstrated an average increase of $4.29 \mathrm{~T}$-units in their writing samples, from an average of $8.00 \mathrm{~T}$-units at the beginning of the program to $12.29 \mathrm{~T}$-units at the end. In addition, students used, on average, 34 more words in their writing samples at the end of the program than at the beginning of the program.

In addition to writing length measures, the total number of unique words used in writing samples was measured. The mean and standard error for the total number of different words used in both pre- and post-program written narratives are displayed in Table 4-3. A significant difference was found from the pre-program assessment to postprogram assessment $(t=-3.199, \mathrm{p}<.01)$ with students demonstrating an average increase of 12 unique vocabulary words in their writing.

Sentence complexity, defined as use of subordinate clauses, was also assessed. Students demonstrated no significant changes in the use of subordinate clauses $(t=-$ $1.794, \mathrm{p}=0.096)$. On average, students demonstrated $.36(\mathrm{SE}=.29)$ subordinate clauses per writing sample at the beginning of the program, and .71 $(\mathrm{SE}=.35)$ at the conclusion of the program. Only two of the fourteen students included a subordinate clause in their pre-program writing, which increased to four students at the post-program assessment.

\section{Summer Learning Loss}

To examine summer learning loss, an oral reading fluency (ORF) and a retell fluency (RTF) curriculum-based measure (CBM) were administered weekly. Results for the ORF are shown below in Figure 4-1. A repeated measures ANOVA $(\mathrm{N}=22)$ revealed no significant differences for the six ORF measurements. This indicates that students did not demonstrate a significant increase or decrease in oral reading fluency during the six-week intervention period.

The RTF-CBM was also administered weekly to the students as a measure of reading comprehension. The $\mathrm{RTF}$ is designed to be administered only to students that are reading 40 or more words per minute. A student meets the standards for demonstrating adequate comprehension skills if they have a RTF score of $25 \%$ or higher. Table $4-4$ shows the number of students out of a total of 22 students, that met the required 40 words per minute per week, as well as the percentage of students that met the RTF adequate 
Table 4-2. Means and SE for writing length

\begin{tabular}{lcclcc}
\hline Intervention & \multicolumn{2}{c}{ Total T-units } & & \multicolumn{2}{c}{ Total Words } \\
\cline { 2 - 3 } \cline { 6 - 6 } & Mean & SE & & Mean & SE \\
\hline Pre-test & 8.00 & 1.17 & & 50 & 9.52 \\
Post-test & $12.29^{*}$ & 1.77 & & $84^{*}$ & 16.04 \\
\hline
\end{tabular}

$*$ Significant at the $\mathrm{p}<.05$

Table 4-3. Means and SE for total number of unique words

\begin{tabular}{lcc}
\hline Intervention & \multicolumn{2}{c}{ Total Different Words } \\
\cline { 2 - 3 } & Mean & SE \\
\hline Pre-test & 30 & 5.54 \\
Post-test & $42^{*}$ & 7.06 \\
\hline
\end{tabular}

* Significant at the $\mathrm{p}<.05$ 


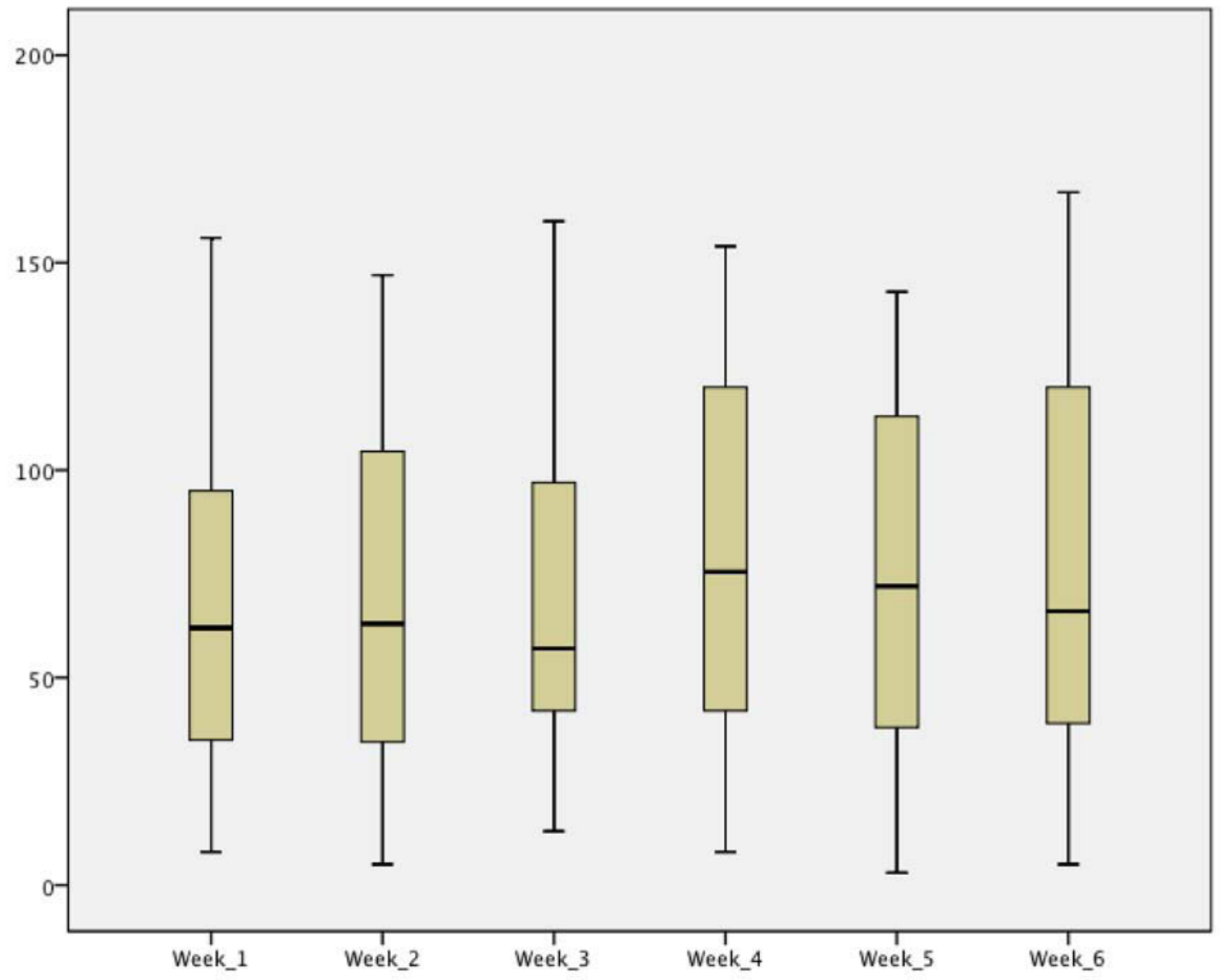

Figure 4-1. Oral Retell Fluency (ORF) performance 
Table 4-4. Retell Fluency (RTF) student means and range

\begin{tabular}{|c|c|c|c|c|}
\hline $\begin{array}{l}\text { Intervention } \\
\text { Week }\end{array}$ & $\begin{array}{l}\text { N Students } \\
\text { with } 40+ \\
\text { Words in ORF }\end{array}$ & $\begin{array}{l}\text { RTF Scores of } \\
25 \%+\end{array}$ & Mean & Range \\
\hline Week One & 18 & $4(22 \%)$ & $17 \%$ & $9 \%-36 \%$ \\
\hline Week Two & 19 & $10(53 \%)$ & $32 \%$ & $10 \%-77 \%$ \\
\hline Week Three & 20 & $14(70 \%)$ & $41 \%$ & $16 \%-87 \%$ \\
\hline Week Four & 20 & $16(80 \%)$ & $39 \%$ & $18 \%-90 \%$ \\
\hline Week Five & 21 & $14(67 \%)$ & $29 \%$ & $18 \%-73 \%$ \\
\hline Week Six & 19 & $14(74 \%)$ & $34 \%$ & $21 \%-73 \%$ \\
\hline
\end{tabular}

comprehension score requirement (i.e., a retell score of at least $25 \%$ of their oral reading fluency score). Results for all RTF scores are shown below in Figure 4-2. A repeated measures ANOVA revealed no significant differences for the six RTF measurements. This indicates that students did not demonstrate an increase or decrease in retell fluency during the six-week intervention period.

\section{Results of Individual Goals and Objectives}

Individual results were recorded for students receiving individual or small group treatment from the SLP assistants. Overall, students achieved their individual goals and objectives (see Appendix I for all individual results). All goals and objectives aligned with the goals of the literacy program as well as the Tennessee state standards for grade level performance. 


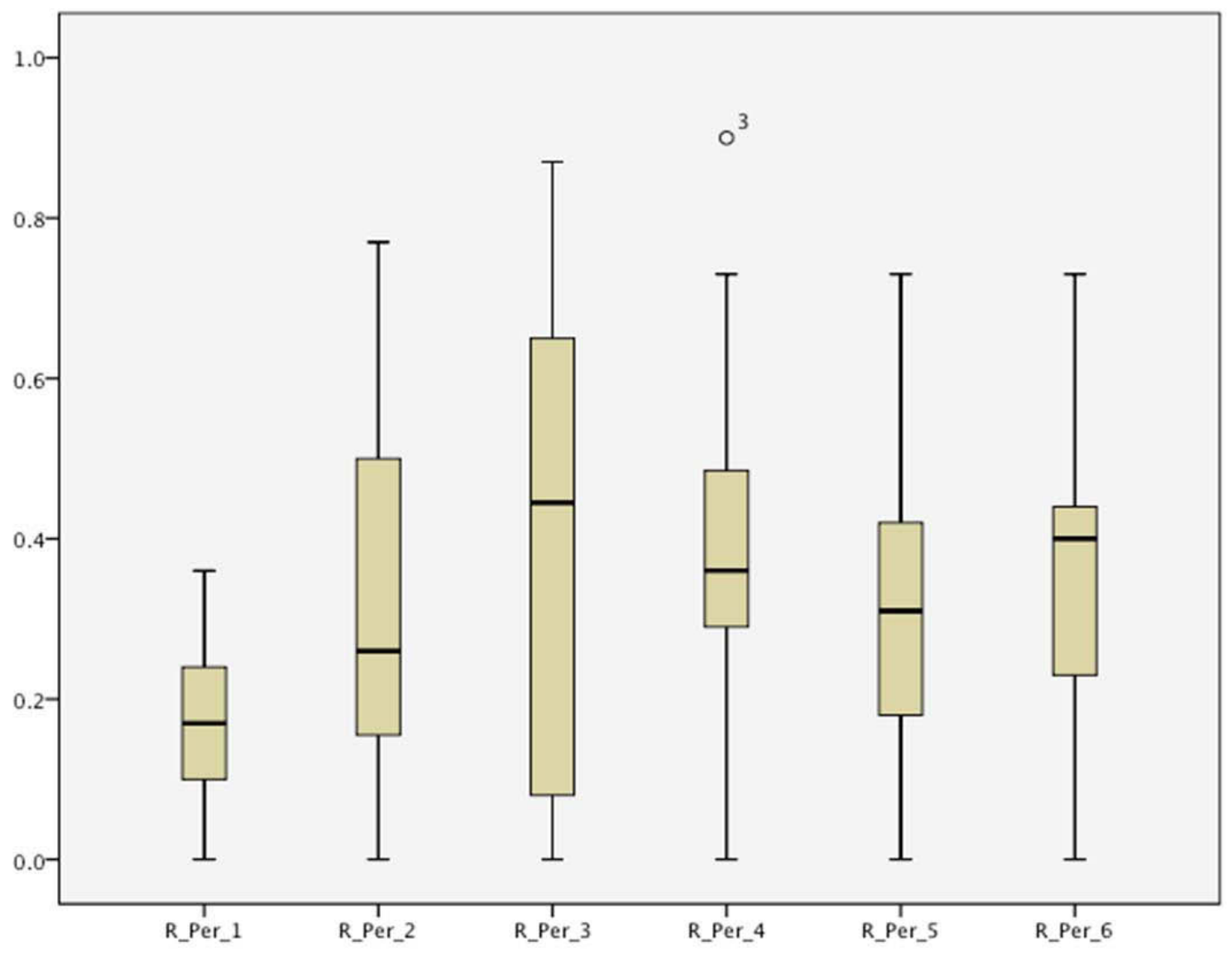

Figure 4-2. Retell Fluency (RTF) performance 


\section{CHAPTER 5. DISCUSSION}

The present study was conducted to explore the effectiveness of a summer literacy program designed to improve the oral and written narrative abilities and reduce the occurrence of summer learning loss for students from low SES homes. The program was affiliated with a local ministry and all 22 participants attended the same area public school. The summer literacy program incorporated community experiences with repeated and varied interactions with relevant texts. In addition, exposure to and interaction with texts was combined with strategic written instruction in which students were given opportunities to write for authentic purposes.

\section{Interpretation of the Results}

Based on previous studies (Farkas \& Beron, 2004; Hart \& Risley, 1995), it was hypothesized that the students from low SES homes would demonstrate significantly lower vocabulary skills than the norm on a standardized test. Performance on the PPVT-4 demonstrated an average standard score of 83.19 on receptive vocabulary, which is one standard deviation below the mean of the normative sample. Thus, the students from low SES homes, grades 1-5, presented with deficiencies in receptive vocabulary. In addition to vocabulary deficits, students also demonstrated significantly lower scores on measures of non-verbal intelligence, passage comprehension, and oral narrative abilities when compared to available normative data.

Interestingly, word identification and word attack skills (i.e., decoding) were within normal limits based on normative data. Scores on the Word Attack and Word Identification subtests of the WRMT-R were very close to the mean of the normative sample. This result is consistent with research which found that students from low SES homes demonstrate adequate decoding skills but below average comprehension (Catts \& Kahmi, 2005). This may be due to the fact that decoding, or the ability to sound out words, is a skill that is heavily emphasized in the public school setting (Berninger et al., 2001). This implies that the participants in this program are capable of average performance when the skill being tested is a focus of their curriculum.

To address deficits in comprehension, the teaching focus of this summer literacy program was on oral and written narratives. It was hypothesized that the use of evidencebased practices such as read alouds, visual strategies, story mapping and strategic writing instruction would improve oral and written narratives. Results of the program demonstrated that there were significant changes in both.

Prior to program entry, students had initial NSS scores that were significantly lower than the normative sample; however, normative data are only available for one text per grade. Therefore, the NSS scores are a static measure of one-time performance. To monitor progress, texts similar in length and structure by the same author were chosen for pre- and post-program samples to assess changes in narrative skills. Students 
demonstrated a significant increase in narrative ability from pre- to post-literacy program participation. Scores improved from an average of 22 prior to the program to an average of 25 at the completion of the program on the pre- and post-intervention assessments, respectfully. According to narrative development theory (Applebee, 1978; Roth et al., 2002; Westby, 1991), by age four and a half children include characters emotional states in their oral narratives. This study demonstrated that after explicit and repeated exposure to narrative structure and story grammar, students improved their overall narrative abilities, specifically in the areas of character development and referencing characters in their narrative retells. Findings also show that school age children can continue to make significant gains in narrative discourse and structure.

To address written narratives, students participated in a writing center for thirty minutes each day, strategically structured to provide opportunities to generate meaningful compositions for authentic audiences. It was hypothesized that written outcomes would significantly improve as a result of the summer program. After six weeks in the literacy program, which utilized a modified version of Strategic and Interactive Writing Instruction (SIWI, Wolbers, 2007), students made significant gains on written narrative outcomes. From pre-program to post-program assessments, students significantly increased the number of T-units, the total number of words and the total number of unique words used in their personal written narratives. This is consistent with previous research that demonstrates SIWI is an effective instructional method for students with written language deficits from special populations (Wolbers et al., 2012). These positive results for written narratives support a relationship between explicit instruction in the process of writing using visual scaffolds and improved narrative expression (Pritchard \& Honeycutt, 2006).

There is substantial evidence that students from low SES homes demonstrate what has been referred to as summer learning loss (Alexander et al., 2007; Cooper et al., 1996; Cooper et al., 2000; Lee et al., 2007; McGill-Franzen \& Allington, 2003). It was hypothesized that students that participated in the summer reading program would not show a loss of reading fluency skills as measured by weekly oral reading fluency (ORF) CBM's. Reading fluency, or decoding ability, was not directly addressed during the summer literacy program, therefore, no significant improvement was expected. As expected, no significant gains were noted for the ORF measure. However, it is important to note that because the students in this study did not demonstrate the loss typical of children from low SES homes during the six week intervention time period, oral and written narrative instruction may be a valuable component of any summer literacy program

In general, reading comprehension is an ultimate goal of literacy programs. This program used oral and written narratives as a means of addressing literacy deficits. Prior to the program, the children in this study demonstrated lower than average reading comprehension and narrative scores as measured by standardized assessments. Due to the short duration of the program, a standardized test for reading comprehension could not be readministered. To track reading comprehension skills, children who were eligible based 
on reading fluency scores (i.e., at least 40 words per minute) were administered a weekly curriculum based reading comprehension measure. No changes in reading comprehension as measured by the RTF were noted for the group. Oral and written narrative instruction may have served to allow the children to maintain their reading skills. While these results cannot be generalized to the entire summer, if the students in this study demonstrated no loss of either decoding or reading comprehension skills during the six-week intervention time period, the program may have succeeded in preventing summer learning loss even on critical literacy skills that were related but not targeted.

\section{Theoretical Implications}

This study was based on the underpinnings of socio-cultural theory, and literacy instruction was provided within social interactions. The program combined reading and writing activities and interrelated community experiences to provide meaningful contexts for students to engage with and understand written text (Englert, Mariage \& Dunsmore, 2006; Hart \& Risley, 1995; Vygotsky, 1978). With guidance from college interns and SLP graduate clinicians, students were provided scaffolds and instructional supports to facilitate learning new material. This study provides evidence to support using a model that involves knowledgeable adults to improve literacy skills.

Further, this study was based on what Wertsch termed mediated action (1991), where being actively engaged in events and cultural experiences is a productive and effective method of learning. To this end, Wertsch stressed the importance of the connection between language and social contexts. This study aimed to intertwine community experiences with increased exposure to and interaction with related and culturally relevant texts. The combination of literacy activities with related active and engaging experiences in the community contributed to the positive results of the study.

\section{Implications for Research and Practice}

Although community groups are known to provide emotional, spiritual, physical and academic support to students in need, there little evidence to support the participation of these organizations as resources to improve academic skills for students. This successful pilot study demonstrates the need for larger-scale experimental research of similar interventions. Summer programs provide an important opportunity for meeting the academic needs of students from low SES homes. Community organizations may be in an excellent position to make a positive contribution to their literacy needs in addition to the other areas of support they are already serving.

For this study, I worked very closely with the program coordinator for SOAR Youth Ministries. Her contributions to the provision of local community experiences for the students at a reduced fee or free of charge were invaluable. Her working relationships with many local area organizations allowed the participants to visit the local Minor League baseball team, a dinner cruise boat, the zoo, the local fire department and other 
community establishments. She was also able to obtain food donations from area grocery stores for cooking class experiences. All of these activities were made possible by the longstanding relationships between SOAR and local businesses.

My experience working with the staff at SOAR was a very positive one. I believe that our combined skills provided a unique and more effective program than would not have occurred if we had undertaken this project individually. In previous years, standard curriculum sets were purchased for the academic portion of the summer program at SOAR. These published programs can be expensive, and the staff are limited to using whatever literacy materials are included. In this model, thematic units that were relevant to the students' interests were implemented with classroom texts that matched the community experiences. The primary researcher chose texts that matched the student's reading abilities and grade levels. Thus, the combination of a SLP coordinator with a community outreach program coordinator proved to be a successful partnership for creating and implementing a summer reading program.

\section{Limitations}

The sample for this study was acquired from an ongoing ministry program in the community and all children attended the same public school during the school year. Therefore, the sample does not necessarily represent a true sample population of students from low SES homes. The summer program is also faith based, so parents who were not interested in having their children attend a program with a faith based ministry may not have participated. While flyers inviting student participation were posted in local schools and in local community areas, not all community members may have been aware of the summer program opportunity.

This research utilized a one-group, pre-post assessment design. As such, it is possible that differences between pre- and post program assessment scores may be due to maturation, as well as possible regression to the mean (i.e., increases between pre and post-assessment are due to extremely low pre-assessment scores). While there is well documented evidence that students from low SES homes experience summer learning loss, further research using a larger experimental group in addition to a matched control group is warranted to strengthen the findings of future research.

The length of the writing samples and number of students that were able to produce a written narrative limited the way the data could be analyzed. Of the students that were able to produce a writing sample at pre- and post- assessment, several were too short in length to use a primary traits rubric to assess changes in higher-level writing skills (eg., cohesion).

Another limitation in this study relates to the difficulty posed by selecting participants from low SES homes and their inconsistent program participation. Although statistics report that $20 \%$ of all schools are considered "high poverty" schools, there are problems associated with finding large numbers of students from this population for the 
purposes of research during the summer. Like previous studies, inconsistent attendance was an issue in this program (White \& Johnston, 1999; Johnston, 2000; HarringtonLueker, 2000). Research has shown that students from low SES homes are often "transient", and may often move multiple times over a short period. For our particular study, there were several families whose country of origin was not the U.S., and some of them left in the middle of the summer to return to their home country. Transportation for summer programs can also be an issue if not provided by the researcher or program (Pokorni, Worthington \& Jamison, 2010). At the beginning of the summer literacy program, 36 students were registered to participate. However, due to inconsistent attendance, behavior and transient living situations, data from only 22 students were included in the current study. Further, data were available for only 19 students for all the standardized assessment measures and only 15 students for pre- and post writing samples.

\section{Future Implications}

It is clear from the literature and from this current study that students from low SES homes benefit from summer literacy programs (Cirrin \& Gillam, 2008). This study demonstrated that a summer literacy program sponsored by a community ministry in collaboration with educators can improve oral narrative discourse and written narrative abilities, as well as prevent summer learning loss for reading fluency and reading comprehension. In the absence of certified classroom teachers, students from low SES homes were able to successfully improve oral and written narrative abilities under the guidance of student interns who were mentored by the program coordinator and graduate students in speech-language pathology who were supervised by a certified SLP. Future programs providing instruction that combines narrative discourse, strategic writing instruction and varied community experiences should be implemented and findings examined. A study with a control group should also be undertaken to make clear that the positive results of this study were related to instruction and not the effects of maturation or regression to the mean.

\section{Conclusion}

In summary, the current study investigated the effectiveness of a summer literacy program for low SES students designed to increase oral and written narrative skills and reduce summer learning loss. Students made significant gains during the summer program in narrative skills and written expression. No significant decreases in reading fluency or reading comprehension were noted. Additionally, oral and written narrative skills significantly improved. I recently had the opportunity to revisit the program site and speak to two young girls that participated in the literacy program. Each student was able to recount all of the themes from the program, as well as retell story after story from the program community activities, their favorite book. They also expressed a desire to participate in the summer program this year. It was this experience that made me realize that as professionals we know we must provide evidence-based practices for students, however, it is equally critical that we meet the needs of our students by providing 
meaningful and memorable experiences. Life experiences and enhanced world knowledge provide the background and foundation for understanding and enjoying the written word and should serve as a foundation for future work with this population. 


\section{LIST OF REFERENCES}

Adlof, S., Catts, H. \& Little, T. (2006). Should the simple view of reading include a fluency component? Reading and Writing, 19, 933-958.

Alexander, K., Entwisle, D. \& Olson, L. S. (2007). Lasting consequences of the summer learning gap. American Sociological Review, 72(1), 167-180.

Allinder, R., Fuchs, L., Fuchs, D. \& Hamlett, C. (1992). Effects of summer break on math and spelling performance as a function of grade level. The Elementary School Journal, 92, 451-460.

Allington, R. , \& Johnston, P. (2002). Reading to learn: Lessons from exemplary fourthgrade classrooms. New York: Guilford.

Allington, R., \& McGill-Franzen, A. (2009). Comprehension difficulties among struggling readers. In S. Israel \& G. Duffy (Eds.), Handbook of research on reading comprehension (pp. 551-568). New York: Routledge.

Allington, R., McGill-Franzen, A., Camilli, G., Williams, L., Graff, J., Zeig, J., Zmach, C. \& Nowak, R. (2010). Addressing summer reading setback among economically disadvantaged elementary students. Reading Psychology, 31(5), $411-27$.

Allor, J. \& McCathren, R. (2004). The efficacy of an early literacy tutoring program implemented by college students. Learning Disabilities Research and Practice, 19(2), 116-129.

Apel, K \& Thomas-Tate, K. (2009). Morphological awareness skills of fourth-grade African American students. Language, Speech and Hearing Services in Schools, 40, 312-324.

Applebee, A. (1978). The child's concept of a story. Chicago: University of Chicago Press.

Applebee, A. (1984). Writing and reasoning. Review of Educational Research 54:4, 577 596.

Applebee, A. (2000). Perspectives in writing: Research, theory, and practice. R. Indrisano \& J. R. Squire, Eds., Newark, DE: International Reading Association.

Apte, U., Karmarkar, U. \& Nath, H. (2008). Information services in the U.S. economy: Value, jobs, and management implications. California Management Review, $50(3), 12-30$. 
Arnold, D., Lonigan, C., Whitehurst, G. \& Epstein, J. (1994). Accelerating language development through picture book reading: Replication and extension to a videotape training format. Journal of Educational Psychology, 86, 235-243.

Arthaud, T. J., \& Goracke, T. (2006). Implementing a structured story web and outline strategy to assist struggling readers. The Reading Teacher, 59(6), 581-586.

Aud, S., Hussar, W., Planty, M., Snyder, T., Bianco, K., Fox, M., Frohlich, L., Kemp, J., Drake, L. (2010). The Condition of Education 2010 (NCES 2010-028). National Center for Education Statistics, Institute of Education Sciences, U.S. Department of Education. Washington, DC.

Austin, G., Roger, B. \& Walbesser, H. (1972). The effectiveness of summer compensatory education: A review of the research. Review of Educational Research, 42, 171-181.

Barnes, S. (2008). The least of these: Black church children's and youth outreach efforts. Journal of African American Studies, 12, 97-119.

Berninger, V., Abbott, R., Billingsley, F. \& Nagy, W. (2001). Processes underlying timing and fluency: Efficiency, automaticity, coordination, and morphological awareness. In M. Wolf (Ed.), Dyslexia, fluency, and the brain (pp. 383-414). Baltimore: York Press.

Brown, L., Sherbenou, R. \& Johnsen, S. (1997). Test of nonverbal intelligence (3rd ed). Austin, TX: Pro-Ed.

Bruner, J. (1986). Actual minds, possible worlds. Cambridge, MA: Harvard University Press.

Burkham, D., Ready, D., Lee, V. \& LoGerfo, L. (2004). Social-class differences in summer learning between kindergarten and first grade: Model specification and estimation. Sociology of Education, 77, 1-31.

Bus, A. (2003). Social-emotional requisites for learning to read. In A. van Kleeck, S. A. Stahl, \& E. B. Bauer (Eds.), On reading books to children: Parents and teachers (pp. 3-15). Mahwah, NJ: Lawrence Erlbaum.

Catts, H., Fey, M., Tomblin, J. \& Zhang, X. (2002). A longitudinal investigation of reading outcomes in children with language impairments. Journal of Speech, Language, and Hearing Research, 45, 1142-1157.

Catts, H. \& Kamhi, A. (2005). Language and reading disabilities. Boston, MA: Allyn \& Bacon. 
Cirrin, F. \& Gillam, R. (2008). Language intervention practices for school-age children with spoken language disorders: A systematic review. Language, Speech, and Hearing Services in Schools, 39, 110-137.

Cobb, J. B. (2001). The effects of an early intervention program with preservice teachers as tutors on the reading achievement of primary grade at risk children. Reading Horizons, 41(3), 155-173.

Cohen, J. (1988). Statistical power analysis for the behavioral sciences (2nd ed.). Hillsdale, NJ: Eribaum.

Cooper, H., Charlton, K., Valentine, J. \& Muhlenbruck, B. (2000). Making the most of summer school: A meta-analytic and narrative review. Monograph Series for the Society for Research in Child Development, 65(1).

Cooper, H., Nye, B., Charlton, K., Lindsay, J. \& Greathouse, S. (1996). The effects of summer vacation on achievement test Scores: A narrative and meta-analytic review. Review of Educational Research, 66(2), 27-68.

Corden, R. (2007). Developing reading-writing connections: The impact of explicit instruction of literary devices on the quality of children's narrative writing. Journal of Research in Childhood Education, 21(3), 269-289.

Davis, Z. T. (1994). Effects of prereading story mapping on elementary readers' comprehension. Journal of Educational Research, 86, 353-360.

Dickinson, D. \&Snow, C. (1987). Interrelationships among pre-reading and oral language skills in kindergartners from two social classes. Early Childhood Research Quarterly, 2,1-25.

Dickinson, D. \& Smith, M. (1994). Long-term effects of preschool teachers' book readings on low-income children's vocabulary and story comprehension. Reading Research Quarterly, 29, 104-122.

Dimino, J., Taylor, R. \& Gersten, R. (1995). Synthesis of the research on story grammar as a means to increase comprehension. Reading and Writing Quarterly: Overcoming Learning Difficulties, 11(1),53-72.

Duke, N. (2000). For the rich it's richer: Print environments and experiences offered to first-grade students in very low- and very high-SES school districts. American Educational Research Journal, 37, 456-457.

Duke, N. \& Pearson, P. (2002). Effective practices for developing reading comprehension. In A. E. Farstrup \& S. J. Samuels (Eds.), What research has to say about reading instruction (3rd ed., pp. 205-242). Newark, DE: International Reading Association. 
Dunn, L. \& Dunn, D. (2007). Peabody picture vocabulary test - IV . Bloomington, MN: Pearson, Inc.

Englert, C., Mariage, T. \& Dunsmore, K. (2006). Tenets of sociocultural theory in writing instruction research. In C. A. MacArthur, S. Graham, \& J. Fitzgerald (Eds.), Handbook of writing research (pp. 208-221). New York: The Guilford Press.

Englert, C. S., \& Thomas, C. C. (1987). Sensitivity to text structure in reading and writing: A comparison between learning disabled and non-learning disabled students. Learning Disability Quarterly, 10(2), 93-105.

Entwistle, D. \& Alexander, K. (1992). Summer setback: Race, poverty, school composition, and mathematics achievement in the first two years of school. American Sociological Review, 57, 72-84.

Farkas, G. \& Beron, K. (2004). The detailed age trajectory of oral vocabulary knowledge: Differences by class and race. Social Science Research, 33, 464-97.

Flanagan, O. (1992). Consciousness reconsidered. Cambridge, MA: The MIT Press.

Flower, L., \& Hayes, J. (1981). A cognitive process theory of writing. College Composition and Communication, 32(4), 365-387.

Flower, L. S., \& Hayes, J. R. (1980). The dynamics of composing: Making plans and juggling constraints. In L. W. Gregg \& E. R. Steinberg (Eds.), Cognitive processes in writing (pp. 31-50). Hillsdale, NJ: Erlbaum \& Associates.

Foster, W. \& Miller, M.(2003). Development of the literacy achievement gap: A longitudinal study of kindergarten through third grade. Language, Speech and Hearing Services in Schools, 38, 173-181.

Goals 2000: Educate America Act (P.L. 103-227, Sec. 102).

Good, R. III \& Kaminski, R. (Eds.). (2002). Dynamic indicators of basic early literacy skills (6th ed.). Eugene: University of Oregon, Institute for the Development of Educational Achievement.

Gough, P. \& Tunmer, W. (1986). Decoding, reading, and reading disability. Remedial and Special Education, 17(1), 6-10.

Grossman, J., Walker, K. \& Raley, R. (2001, April). Challenges and opportunities in after-school programs: Lessons for policymakers and funders. Philadelphia: Public/ Private Ventures. 
Harlwell, M., Maeda, Y. and Lee, K. (2004, April). Replicating and extending White's (1982) meta-analysis of the relationship between SES and student achievement. Paper presented at the annual meeting of the American Educational Research Association, San Diego, CA.

Hart, B. \& Risley, T. (1995). Meaningful differences in the everyday experience of young American children. Baltimore, MD: Brookes.

Heath, S. (1983). Ways with words: Language, life, and work in communities and classrooms. Cambridge, England: Cambridge University Press.

Heilmann, J., Miller, J. \& Nockerts, A. (2010). Sensitivity of narrative organization measures using narrative retells produced by young school- age children. Language Testing, 27(4), 603-626.

Hedberg, N. \& Westby, C. (1993). Analyzing storytelling skills: Theory to practice. Tucson, AZ: Communication Skill Builders.

Hemphill, F. \& Vanneman, A. (2011). Achievement Gaps: How Hispanic and White Students in Public Schools Perform in Mathematics and Reading on the National Assessment of Educational Progress (NCES 2011-459). National Center for Education Statistics, Institute of Education Sciences, U.S. Department of Education. Washington, DC.

Heyns, B. (1978). Summer learning and the effects of schooling. New York: Academic Press.

Hillocks, G. (2006). Narrative writing: Learning a new model for teaching. Portsmouth, NH: Heinemann.

Hutson - Nechkash, P. (2001). Narrative toolbox: Blueprints for storybuilding. Eau Claire, WI: Thinking Publications.

Klecan-Aker J. \& Brueggeman L (1991). The Expression Connection. Vero Beach, FL: Speech Bin.

Klecan-Aker, J. \& Caraway, (1997). A study of the relationship of storytelling ability and reading comprehension in fourth and sixth grade African-American children. European Journal of Disorders of Communication, 32, 109-125.

Klecan-Aker, J. \& Kelty, K. (1990). An investigation of the oral narratives of normal and language-learning disabled children. Journal of Childhood Communication Disorders, 13, 207-216. 
Lauer, P., Akiba, M., Wilkerson, S., Apthorp, H., Snow, D. \& Martin-Glenn, M. (2006). Out-of-school-time programs: A meta-analysis of effects for at-risk students. Review of Educational Research, 76, 275-313.

Lee, J., Grigg, W. \& Donahue, P. (2007). The nation's report card: Reading 2007. Washington, DC: National Center for Education Statistics.

Lester, H. (1986). A porcupine named Fluffy. Boston, MA: Houghton Mifflin.

Lester, H. (1987). Pookins gets her way. Boston, MA: Houghton Mifflin.

Lincoln, C. E., \& Mamiya, L. (1990). The Black church in the African-American experience. Durham: Duke University Press.

Lonigan, C. J., Anthony, J. L., Bloomfield, B. G., Dyer, S. M. \& Samwel, C. S. (1999). Effects of two shared-reading interventions on emergent literacy skills of at-risk preschoolers. Journal of Early Intervention, 22, 306-322.

Lorenz, B., Green, T. \& Brown, A. (2009), Using Multimedia Graphic Organizer Software in the Prewriting Activities of Primary School Students: What Are the Benefits?, Computers in the Schools, 26:2, 115-129.

Mandler, J. \& Johnson, N. (1977). Remembrance of things parsed: Story structure and recall. Cognitive Psychology, 9, 111-151.

Mayer, M. (1969). Frog, where are you? New York, NY: Dial.

Mays, B. \& Nicholson, J. (1933). The negro's church. New York: Institute of Social and Religious Research.

McGill-Franzen A. \& Allington, R. (2003). Bridging the summer reading gap. Scholastic Instructor, 112:8, 17-20.

Meyer, D. (1995). The effects of graphic organizers on the creative writing of thirdgrade students. Research Project, Kean College of New Jersey. (ERIC Document Reproduction Service No. ED380803).

Miller, W. (1999). Night golf. New York, NY:. Lee and Low Books, Inc.

Miller, J. F., \& Chapman, R. S. (2008). Systematic Analysis of Language Transcripts (Version 8) [Computer software]. Madison, WI: University of WisconsinMadison, Waisman Center, Language Analysis Laboratory.

Montgomery, J. (2008). Models of RTI for SLPs: Is this what we have been waiting for? Perspectives on Language Learning and Education, 15, 13-21. 
Morrow, L. M. (1992). The impact of a literature-based program on literacy achievement, use of literature, and attitudes of children from minority backgrounds. Reading Research Quarterly, 27(3), 250- 276.

Mowbray, C., Holter, M., Teague, G. \& Bybee, D. (2003). Fidelity criteria: development, measurement, and validation. American Journal of Evaluation, 24, 315-340.

Myers L. \& Botting, N. (2008). Literacy in the mainstream inner-city school: Its relationship to spoken language. Child Language Teaching and Therapy 24: 95114.

Nation, K., Cocksey, J., Taylor, J., \& Bishop, D. (2010). A longitudinal investigation of early reading and language skills in children with poor reading comprehension. Journal of Child Psychology and Psychiatry, 51(9), 1031-1039.

National Commission on Writing in America's Schools and Colleges. (2006). Writing and school reform. New York: College Entrance Examination Board.

National Reading Panel. (2000). Teaching children to read: An evidence-based assessment of the scientific research literature on reading and its implications for reading instruction. Washington, DC: U.S. Department of Health and Human Services, Public Health Service, National Institutes of Health, and the National Institute of Child Health and Human Development.

Nelson, N. (2010). Changes in story probes written across third grade by African American and European American students in a writing lab approach. Topics in Language Disorders, 30:3, 223-252.

Nelson, N. \& Van Meter, A. M. (2007). Measuring written language ability in narrative samples. Reading and Writing Quarterly, 23(3), 287-309.

NICHD Early Child Care Research Network (2005). Pathways to reading: The role of oral language in the transition to reading. Developmental Psychology 41, 428-42.

No Child Left Behind Act of 2001. (2002). Public Law 107-110.

Norris, J. \& Bruning, R. (1988). Cohesion in the narratives of good and poor readers. Journal of Speech and Hearing Disorders, 53, 416 - 424.

Perie, M., Grigg, W. \& Donahue, P. (2005). The nation's report card: Reading 2005 (NCES 2006-451). Washington, DC: U.S. Department of Education, National Center for Education Statistics.

Pressley. M., Allington, R., Wharton-McDonald, R., Block, C. \& Morrow, L. (2001). Learning to read: Lessons from exemplary first-grade Classroom, New York, NY: Guilford Press. 
Pritchard, R. \& Honeycutt, J. (2006). Process writing: Handbook of writing research. New York, NY: Guilford Press.

Pullen, P., Lane, H. \& Monaghan, M. (2004). Effects of a volunteer tutoring model on the early literacy development of struggling first-grade students. Reading Research and Instruction, 43(4), 21-40.

Purcell-Gates, V., McIntyre, E. \& Freppon, P. (1995). Learning written storybook language in school: A comparison of low- SES children in skills-based and whole language classrooms. American Education Research Journal, 32, 659-685.

Reutzel, D. (1984). Story mapping: An alternative approach to comprehension. Reading World, 24:1, 18-25.

Reutzel, D., Hollingsworth, P. \& Eldredge, J. (1994). Oral reading instruction: The impact on student reading development. Reading Research Quarterly, 29, 40-62.

Roth, F., Speece, D. \& Cooper, D. (2002). A longitudinal analysis of the connection between oral language and early reading. The Journal of Educational Research, 95, 259-272.

Rumberger, R. (2007) Parsing the Data on Student Achievement in High-Poverty Schools. North Carolina Law Review, 85: 1293-1314.

Shaywitz, S. (2003). Overcoming dyslexia: A new and complete science-based program for reading problems at any level. New York: Knopf.

Snow, C. (1991). The theoretical basis for relationships between language and literacy development. Journal of Research in Childhood Education, 6, 5-10.

Snow, C. (2002). Reading for understanding: Toward an $R \& D$ program in reading comprehension. Santa Monica, CA: RAND Corporation.

Snow, C. \& Ninio, A. (1986). The contracts of literacy: What children learn from learning to read books. In W. H. Teale \& E. Sulzby (Eds.), Emergent literacy: Writing and reading (pp. 116-138). Norwood, NJ: Ablex Publishing.

Speece, D., Roth, F., Cooper, D. \& De La Paz, S. (1999). The relevance of oral language skills to early literacy: A multivariate analysis. Applied Psycholinguistics, 20, 167-190.

Steig, W. (1982). Doctor De Soto. New York, NY: Farrar, Straus and Giroux.

Storch, S. \& Whitehurst, G. (2002). Oral-language and code-related precursors to reading: Evidence from a longitudinal structural model. Developmental Psychology, 38, 934-937. 
Stothard, S. E., Snowling, M. J., Bishop, D. V. M., Chipchase, B. B., \& Kaplan, C. A. (1998). Language-impaired pre-schoolers: A follow-up into adolescence. Journal of Speech, Language, and Hearing Research, 41, 407-418.

Tam, H. (1987). CLEAR-Reading recovery summer project, summer 1987. Columbus, $\mathrm{OH}$ : Columbus Public Schools, Department of Evaluation Services. (ERIC Document Reproduction Service No. ED 290 126).

Thomas, V., \& Gorky, P. (1996). Heksenspul met Hennie de heks en de kat Helmer (Winnie the witch) [CD-ROM]. Nieuwegein, the Netherlands: Bombilla.

Thomas, S. Quinn, C. Billingsley A. \& Caudwell, C. (1994). The characteristics of northern black churches with community health outreach programs. American Journal of Public Health, 84:4, 575-579.

U.S. Department of the Treasury. (1999). Investing in Childcare. Washington, D.C.: U.S. Department of the Treasury.

van Dijk, T. \& Kintsch, W. (1983). Strategies of discourse comprehension. New York: Academic Press.

van Kleeck, A. (2007, August 14). SLPs' foundational role in reading comprehension: A response to Alan Kamhi. The ASHA Leader, 12(10), 32-33.

van Kleeck, A., Lange, A. \& Schwarz, A. (2011). The effects of race and maternal education level on children's retells of the Renfrew Bus Story-North American Edition. Journal of Speech, Language, and Hearing Research, 54, 1546-1561.

van Kleeck, A. \& Schuele, C. (1987). Precursors to literacy: Normal development. Topics in Language Disorders, 7, 13-31.

Verhallen, M., Bus, A., \& de Jong, M. (2006). The promise of multimedia stories for kindergarten children at-risk. Journal of Educational Psychology, 98, 410-419.

Vygotsky, L. S. (1978). Mind in society: The development of higher psychological processes. (M. Cole, V. John-Steiner, S. Scribner, \& E. Souberman, Eds.). Cambridge, MA: Harvard University Press.

Welch, M., \& Jensen, J. B. (1990). Write, P.L.E.A.S.E.: A video-assisted strategic intervention to improve written expression of inefficient learners. Remedial and Special Education, 12, 37-47.

Westby, C. E. (1991). Learning to talk - talking to learn: Oral-literate language differences. In C. Simon (Ed.), Communication skills and classroom success (pp. 334-355). Eau Claire, WI: Thinking Publications. 
Wertsch, J. V. (1991). Voices of the mind: A sociocultural approach to mediated action. Cambridge, MA: Harvard University Press.

Whitehurst, G. (1997). Language processes in context: Language learning in children reared in poverty. In L. B. Adamson \& M. A. Romski (Eds.). Research on communication and language disorders: Contribution to theories of language development (pp. 233-266). Baltimore: Brookes.

Wolbers, K. (2007). Using balanced and interactive writing instruction to improve the higher order and lower order writing skills of deaf students. Journal of Deaf Studies and Deaf Education, 13, 255-277.

Wolbers, K. (2008). Strategic and Interactive Writing Instruction (SIWI): Apprenticing deaf students in the construction of English text. International Journal of Applied Linguistics, 156, 299-326.

Wolbers, K., Dostal, H. \& Bowers, L. (2012). “I was born full deaf.” Written language outcomes after one year of Strategic and Interactive Writing Instruction (SIWI). Journal of Deaf Studies and Deaf Education. 17(1): 19-38.

Woodcock, R. (1987). Woodcock Reading Mastery Tests-revised. Circle Pines, $\mathrm{MN}$ :American Guidance Service. 


\section{APPENDIX A. NARRATIVE SCORING SCHEME RUBRIC}

Table A-1. Narrative Scoring Scheme rubric for $A$ Boy, $A$ Dog, and a Frog

\begin{tabular}{|c|c|c|c|}
\hline Characteristic & Proficient - 5 & Emerging - 3 & Minimal / Immature - 1 \\
\hline Introduction & $\begin{array}{l}\text { One day a boy and his dog decided to go to } \\
\text { the woods to search for a pet frog. He } \\
\text { brought a bucket and a net. Once they got to } \\
\text { the woods, the boy looked in the tree for a } \\
\text { frog, but he didn't find one. }\end{array}$ & $\begin{array}{l}\text { A dog and a dog went to the } \\
\text { woods }\end{array}$ & $\begin{array}{l}\text { And he went there. And they } \\
\text { were looking for a frog. }\end{array}$ \\
\hline $\begin{array}{l}\text { Character } \\
\text { Development }\end{array}$ & $\begin{array}{l}\text { ALL characters are mentioned (boy, dog, } \\
\text { frog) } \\
\text { More emphasis on the frog's changing } \\
\text { feelings, the boys attempt to catch the frog, } \\
\text { less emphasis on the dog, the boy and dog } \\
\text { leave, the frog is lonley, he follows the } \\
\text { footprints, he finds the house, he sees the } \\
\text { boy and dog having fun, he asks to join in } \\
\text { use of } 1^{\text {st }} \text { person (ex. And the boy said } \\
\text { "fine! I don't want you as my new pet!") }\end{array}$ & $\begin{array}{l}\text { All characters are mentioned } \\
\text { Main characters (boy and } \\
\text { frog) are not distinguished } \\
\text { from supporting characters } \\
\text { (dog) } \\
\text { No dialogue from the story is } \\
\text { given }\end{array}$ & $\begin{array}{l}\text { Inconsistent mention of } \\
\text { characters } \\
\text { Characters necessary for plot } \\
\text { advancement are not mentioned }\end{array}$ \\
\hline Mental States & $\begin{array}{l}\text { Happy frog on a lily } \\
\text { The frog was scared when the boy tried to } \\
\text { catch him. } \\
\text { The boy was frustrated with the frog } \\
\text { The frog became lonely } \\
\text { The dog and boy were in the bathtub }\end{array}$ & $\begin{array}{l}\text { Some use of the listed mental } \\
\text { states }\end{array}$ & No use of mental states \\
\hline
\end{tabular}


Table A-1. Continued

\begin{tabular}{|c|c|c|c|}
\hline Characteristic & Proficient - 5 & Emerging - 3 & Minimal / Immature - 1 \\
\hline Referencing & $\begin{array}{l}\text { Provide necessary antecedents to pronouns } \\
\text { References are clear throughout the story }\end{array}$ & $\begin{array}{l}\text { Inconsistent use of } \\
\text { referencing } \\
\text { Overuse of proper name } \\
\text { instead of references }\end{array}$ & $\begin{array}{l}\text { Excessive use of pronouns with } \\
\text { no reference } \\
\text { Unaware that the listener cannot } \\
\text { follow who is being referenced }\end{array}$ \\
\hline Conflict Resolution & $\begin{array}{l}\text { The frog was lonely so he followed the boy } \\
\text { and the dogs footprints to their house and } \\
\text { went inside. He saw the boy and dog were } \\
\text { having fun and asked to come in }\end{array}$ & $\begin{array}{l}\text { And the frog went to the } \\
\text { boys house } \\
\text { And he was happy }\end{array}$ & No resolution mentioned \\
\hline Cohesion & $\begin{array}{l}\text { All events in logical order } \\
\text { The boy and dog went in search for a pet } \\
\text { frog; they went to the woods, the started } \\
\text { running toward the pond and saw a happy } \\
\text { frog, the boy jumped in and tried to catch } \\
\text { the frog with his bucket. But the frog } \\
\text { jumped off the lily pad. The frog was scared } \\
\text { of the dog, who was growling. The boy got } \\
\text { his net ready. The boy caught the dog in his } \\
\text { net instead of the frog! The boy was } \\
\text { frustrated. The frog was lonely. He } \\
\text { wondered where the boy and his dog had } \\
\text { gone, so he followed their footprints. The } \\
\text { frog went in the house and saw the boy and } \\
\text { dog taking a bath. They looked happy. }\end{array}$ & $\begin{array}{l}\text { Events are in logical order, } \\
\text { But excessive detail is } \\
\text { provided for minor events } \\
\text { OR } \\
\text { Transitions are unclear } \\
\text { OR minimal detail for } \\
\text { critical events }\end{array}$ & No use of smooth transitions \\
\hline Conclusion & $\begin{array}{l}\text { So the frog jumped into the bathtub. He had } \\
\text { found a new home with the boy and the dog. }\end{array}$ & $\begin{array}{l}\text { So the frog jumped into the } \\
\text { bathtub. }\end{array}$ & $\begin{array}{l}\text { Stop s narrating and the listener } \\
\text { may have to ask if that is the end }\end{array}$ \\
\hline
\end{tabular}




\section{APPENDIX B. WRITING PROMPT AND INSTRUCTIONS}

Personal Narrative Writing Prompt Instructions:

Students should be given as much times as needed to write about a personal experience of their choice. Use the provided lined paper and pencils. Students should be encouraged to "do their best" and turn in their writing to the teacher/intern when they have completed their story. They may include pictures if this will help tell their story.

Students should be given the following prompt:

"You can write about a favorite trip, something interesting that has happened this summer or in the past, or a memorable event in your life".

Teachers/interns should make sure students are engaged in their writing, and encourage them to complete the task. Students should not be given any help in spelling, grammar, or vocabulary. 


\section{APPENDIX C. WEEKLY THEMES AND CLASSROOM TEXTS}

Table C-1. Weekly themes and classroom texts

\begin{tabular}{|c|c|c|c|c|c|c|}
\hline Classroom & $\begin{array}{l}\text { Week 1: } \\
\text { Sports }\end{array}$ & $\begin{array}{l}\text { Week 2: } \\
\text { Animals }\end{array}$ & $\begin{array}{l}\text { Week 3: } \\
\text { Diversity }\end{array}$ & $\begin{array}{l}\text { Week 4: } \\
\text { Travel }\end{array}$ & $\begin{array}{l}\text { Week 5: } \\
\text { Vocations }\end{array}$ & $\begin{array}{l}\text { Week } \\
\text { 6: } \\
\text { Service }\end{array}$ \\
\hline $\begin{array}{l}\text { 1st - 2nd } \\
\text { Grade } \\
\text { Classroom }\end{array}$ & $\begin{array}{l}\text { Out of the } \\
\text { Ball Park }\end{array}$ & $\begin{array}{l}\text { Mabela the } \\
\text { Clever }\end{array}$ & $\begin{array}{l}\text { Margaret } \\
\text { and } \\
\text { Margarita }\end{array}$ & $\begin{array}{l}\text { I Knew } \\
\text { You Could }\end{array}$ & $\begin{array}{l}\text { Mr. } \\
\text { President }\end{array}$ & $\begin{array}{l}\text { The } \\
\text { Earth } \\
\text { Book }\end{array}$ \\
\hline $\begin{array}{l}\text { 3rd - 4th } \\
\text { Grade } \\
\text { Classroom }\end{array}$ & $\begin{array}{l}\text { Jesse } \\
\text { Owens }\end{array}$ & $\begin{array}{l}\text { Owen and } \\
\text { Mzee }\end{array}$ & $\begin{array}{l}\text { Everybody } \\
\text { Cooks Rice }\end{array}$ & Japan & $\begin{array}{l}\text { Barak } \\
\text { Obama }\end{array}$ & $\begin{array}{l}\text { You } \\
\text { Can Be } \\
\text { a Friend }\end{array}$ \\
\hline $\begin{array}{l}\text { 5th Grade } \\
\text { Classroom }\end{array}$ & $\begin{array}{l}\text { Fairway } \\
\text { Phenom }\end{array}$ & Sounder & Rules & $\begin{array}{l}\text { Madagasc } \\
\text { ar Africa }\end{array}$ & $\begin{array}{l}\text { The Kid } \\
\text { Who Ran } \\
\text { for } \\
\text { President }\end{array}$ & Holes \\
\hline
\end{tabular}




\section{APPENDIX D. FIRST AND SECOND GRADE LESSON PLAN EXAMPLES}

\section{Out of the Ballpark}

\section{Day One: Introduction \& Pre story discussion}

I. Have students share what sports they have played or would like to play. Create a chart listing out the different types of sports. Have pictures of typical sports (karate, football, soceer, ete) available to add a picture graphic to the written word.

2. Introduce information about Bascball. Ask the students to share if they have played on a team. Have students with experience with T-ball / baseball tell the students the rules of the game.

3. Review ALL the rules for baseball. Were there any that the class missed?

4. Have the students play a "game $^{-}$of bascball with the bases and positions. Use a bat and ball for additional props. Make sure all of the rules are reviewed.

\section{Read: the rules for baseball}

\section{Activity: Ruling with rules!}

\section{Procedures}

I. Many times, we participate in activities, games, events that have "unwritten" rules. We seem to just know what is expected (ex. church). Have students choose an event (church, a sport, school, an activity) and together write the "rules" or "procedures" so that if a person from another country with NO PRIOR experience were to come, they would know the cxpectations.

2. Review the class rules and expectations of SOAR. How are they the same as regular "school"? How are they different? Are there any class rules that need to be added?

3. Review the importance of having rules, whether for the classroom or sports. Define chaos. What would the classroom look like without rules? Sports? The neighborhood? Government???

4. Introduce the story of the weck. Give a previcw of what the story is about, without reading the story. Show the students the cover, artwork, corresponding baseball card.

5. Have the students pose for their own baseball trading card (to be made later in the week). 


\section{APPENDIX E. THIRD AND FOURTH GRADE LESSON PLAN EXAMPLE}

\section{Jesse Owens}

\section{Day One: Introduction}

I. Ask students what sports they are interested in, or participate in. Write them all together. Have students describe (in order of a typical day) what their practioc looks like. Have studenes describe why they are motivated to work hard at those sports.

2. Show pictures (from the internet) of Jesse Owens in person. Describe his biography.

3. Show on a map where Oakville, Alabama is. Take time to talk about how far from Knoxville, how long it would cake to drive, what other scates are in between TN and AL. Where is Cleveland Ohio?

4. Think about time. Look up "what was life like in 1913"? Review the time line in the back of the book. Have students recreate a larger timeline for the classroom.

5. Identify author and illustrator. Read the author and illustrator profile.

6. K-W-L-Student will identify what they KNOW, and what they want to learn based on prestory discussion.

Read Ist portion of book out loud to class (early life to marriage)

\section{Activity: Story recap}

\section{Procedures}

I. list key points of the beginning of story

2. ask questions about the story that are literal

1. Who is the story about?

2. Where does it take place?

3. Review class timeline and identify where you finished reading. Think about the rest of the story.

4. introduce key vocabulary words

- sharccropping

- pncumonia 


\section{APPENDIX F. FIFTH GRADE LESSON PLAN EXAMPLE}

\section{Fairway Phenom}

\section{Day One: Introduction and pre book discussion}

I. What sports are students interested in? What teams have they played on? Individual sports (running, golf) ? Tcam sports (baskctball, football)?

2. What are the pros and cons of team sports versus individual sports? Which do students prefer? Find a way to chare this information (compare/contrast, on the board, on index cards).

3. Does anyone have experience with golf? Does golf carry a stigma? What is it? Is this true?

4. Delve into what golf looks like today. Does everyone know Tiger Woods? What did he do for the "face" of golf? Bring current articles from Sports Illustrated, newspaper, internet.

5. Define "phenomenal". Why do we think the book is called Fairway Phenom? Define fairway in golf terminology.

6. Complete K-W section of K-W-L chart based on class discussion.

7. As students listen to Chapter One and read Chapter 2, encourage students to write down unfamiliar vocabulary words.

Read out loud as a class: Chapter One (first few pages, maybe 10 minutes)

Read individually: Chapter Two

\section{Activity: Summer Fun}

\section{Procedures}

I. Chapter One gives a decailed description of what life is like for Malik in the summer. What is the expectation for this summer for students? What new experiences at SOAR are the most looking forward to?

2. Have students as a class choose a country that they are most interested in traveling to and/or learning more about during the travel week of the summer program.

3. Malik was able to get his golf clubs from his neighbor. Talk in class about the value of teamwork, neighbors, and surrounding yourselves with positive influences. Brainstorm ways that the class can support each other this summer, including classroom environment. Why is is important to build each other up and edify? What kind of negative effects could succumbing to negative peer pressure have on a person's future? How would it effect Malik? 


\section{APPENDIX G. WEEKLY WRITING LESSON PLAN EXAMPLE}

\begin{tabular}{|c|c|c|}
\hline & Writing Unit & \\
\hline & Purpose & \\
\hline & Author & \\
\hline & Audience & \\
\hline & Publication & \\
\hline & & Monday \\
\hline & $\begin{array}{l}\text { Together } \\
\text { (Guided) }\end{array}$ & $\begin{array}{l}\text { Discuss with the students the purpose, } \\
\text { author, audience, and publication }\end{array}$ \\
\hline Organize & $\begin{array}{l}\text { Student writing } \\
\text { (Shared, } \\
\text { independent) }\end{array}$ & \\
\hline & & Tuesday \\
\hline $\mathbf{W}$ & $\begin{array}{l}\text { Together } \\
\text { (Guided) }\end{array}$ & \\
\hline & $\begin{array}{l}\text { Student writing } \\
\text { (Shared, } \\
\text { independent) }\end{array}$ & \\
\hline & & Wednesday \\
\hline Edit & $\begin{array}{l}\text { Together } \\
\text { (Guided) }\end{array}$ & \\
\hline & $\begin{array}{l}\text { Student writing } \\
\text { (Shared, } \\
\text { independent) }\end{array}$ & \\
\hline & & Thursday \\
\hline & $\begin{array}{l}\text { Together } \\
\text { (Guided) }\end{array}$ & \\
\hline & $\begin{array}{l}\text { Student writing } \\
\text { (Shared, } \\
\text { independent) }\end{array}$ & \\
\hline & & Friday \\
\hline & $\begin{array}{l}\text { Together } \\
\text { (Guided) }\end{array}$ & \\
\hline & $\begin{array}{l}\text { Student writing } \\
\text { (Shared, } \\
\text { independent) }\end{array}$ & \\
\hline
\end{tabular}




\section{APPENDIX H. GRADUATE CLINICIAN WEEKLY LESSON PLAN EXAMPLE}

Lesson Plan for the week of: June $20-24$

Theme: Animals

Grade $\&$ Weekly Book: $5^{\text {th }}$, Sounder

Overall Goals:

1.) Use sentence and word context to find meaning of unknown words (i.e. vocabulary).

\begin{tabular}{|c|c|c|c|c|}
\hline 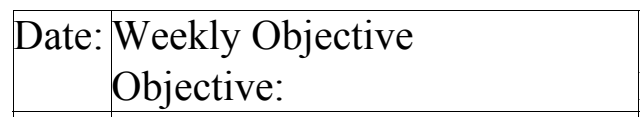 & Materials: & $\begin{array}{l}\text { Activity } \\
\text { Procedures: }\end{array}$ & Data collection: & Plan: \\
\hline $\begin{array}{l}\text { Student will resolve } \\
\text { ambiguities about word and } \\
\text { sentence meanings when given } \\
\text { a grade level story in a small } \\
\text { group in } 4 \text { of } 5 \text { opportunities } \\
\text { ( } 80 \% \text { accuracy). } \\
\text { Student will accurately retell a } \\
\text { paragraph or short story, } \\
\text { recalling important details } \\
\text { (main idea, characters, etc.) } \\
\text { with } 80 \% \text { accuracy. }\end{array}$ & $\begin{array}{l}\text { Sentences/word \& } \\
\text { definition written on note } \\
\text { card or white board. } \\
\text { Aesop's Fables } \\
\text { Picture of map (where), a } \\
\text { person's head (who) and a } \\
\text { question mark (what) }\end{array}$ & $\begin{array}{l}\text { Present sentence with the word in } \\
\text { it, use context clues to find } \\
\text { meaning. } \\
\text { Client gives definition of } \\
\text { word/show picture of word then } \\
\text { ask client to use in a sentence. } \\
\text { Use the pictures to cue the client } \\
\text { as to what to include in his retell } \\
\text { of the story. } \\
\text { Tell client what to listen for } \\
\text { (who, what, when, problem, } \\
\text { resolution) before reading the } \\
\text { story. }\end{array}$ & & \\
\hline
\end{tabular}




\section{APPENDIX I. INDIVIDUAL RESULTS FOR STUDENTS' GOALS AND OBJECTIVES}

\section{Table I-1. Individual results for students' goals and objectives}

\begin{tabular}{|c|c|c|c|}
\hline $\begin{array}{c}\text { Student \# } \\
\text { and } \\
\text { Grade }\end{array}$ & $\begin{array}{c}\text { Intervention } \\
\text { Goals }\end{array}$ & Objectives & Outcomes \\
\hline $\begin{array}{l}\# 1 ; 1 \text { st } \\
\text { Grade }\end{array}$ & $\begin{array}{l}\text { Retell stories } \\
\text { using basic } \\
\text { story grammar, } \\
\text { sequencing } \\
\text { story, events by } \\
\text { and answering } \\
\text { who what } \\
\text { where why and } \\
\text { how questions. }\end{array}$ & $\begin{array}{l}\text { 1. Student will respond accurately } \\
\text { to who, what, where questions in } \\
\text { small group or classroom in } 4 \text { of } 5 \\
\text { opportunities ( } 80 \% \text { accuracy). } \\
\text { 2. Student will accurately sequence } \\
\text { parts of a story in } 4 \text { of } 5 \\
\text { opportunities ( } 80 \% \text { accuracy). } \\
\text { 3. Student will accurately describe } \\
4 \text { out of } 5 \text { story grammar } \\
\text { components with minimal clinician } \\
\text { cueing ( } 80 \% \text { accuracy). }\end{array}$ & $\begin{array}{l}\text { 1. Achieved. Student was able to give comprehensive } \\
\text { answers to questions asked pertaining to a story. Student } \\
\text { was able to respond independently for concrete questions, } \\
\text { but did require moderate cueing (clozed procedure, } \\
\text { rephrasing the question and visual cues) with the more } \\
\text { abstract questions such as how and why. } \\
\text { 2. Achieved. } 100 \% \text { accuracy was achieved; however, } \\
\text { student did require help reading the sentences. } \\
\text { 3. Achieved. Student was able to accurately describe the } \\
\text { story grammar components with the help of visual cues for } \\
\text { the title and clozed procedure for the conflict of the story. }\end{array}$ \\
\hline $\begin{array}{l}\# 2 ; 1 \text { st } \\
\text { Grade }\end{array}$ & $\begin{array}{l}\text { Retell stories } \\
\text { using basic } \\
\text { story grammar, } \\
\text { sequencing } \\
\text { story, events by } \\
\text { and answering } \\
\text { who, what, } \\
\text { where, why and } \\
\text { how questions. }\end{array}$ & $\begin{array}{l}\text { 1. Student will respond accurately } \\
\text { to "wh" questions in small group or } \\
\text { classroom in } 4 \text { of } 5 \text { opportunities } \\
\text { ( } 80 \% \text { accuracy). } \\
\text { 2. Student will accurately describe } \\
4 \text { of } 5(80 \%) \text { story grammar } \\
\text { components. } \\
\text { 3. Student will accurately sequence } \\
\text { parts of a story in } 4 \text { out of } 5 \\
\text { opportunities ( } 80 \% \text { accuracy). }\end{array}$ & $\begin{array}{l}\text { 1. Achieved. Student was able to independently answer } \\
\text { "wh" questions with } 80 \% \text { accuracy by the end of summer. } \\
\text { 2. Progressing. Student demonstrated an increase in story } \\
\text { grammar accuracy, but still required verbal cues. } \\
\text { 3. Achieved. By the end of the summer, the student was } \\
\text { able to sequence stories with } 100 \% \text { accuracy. }\end{array}$ \\
\hline
\end{tabular}


Table I-1. Continued

\begin{tabular}{|c|c|c|c|}
\hline $\begin{array}{c}\text { Student } \\
\text { \# and } \\
\text { Grade }\end{array}$ & $\begin{array}{c}\text { Intervention } \\
\text { Goals }\end{array}$ & Objectives & Outcomes \\
\hline $\begin{array}{l}\# 3 ; 2 \text { nd } \\
\text { grade }\end{array}$ & $\begin{array}{l}\text { Retell stories } \\
\text { using basic } \\
\text { story grammar, } \\
\text { sequencing } \\
\text { story, events by } \\
\text { and answering } \\
\text { who, what, } \\
\text { where, why and } \\
\text { how questions. }\end{array}$ & $\begin{array}{l}\text { 1. Student will respond accurately } \\
\text { to who, what, and where questions } \\
\text { in small group or classroom in } 4 \text { of } \\
5 \text { opportunities ( } 80 \% \text { accuracy). } \\
\text { 2. Student will accurately describe } \\
4 \text { of } 5(80 \%) \text { story grammar } \\
\text { components with minimal clinician } \\
\text { cueing. } \\
\text { 3. Student will accurately sequence } \\
\text { parts of a story in } 4 \text { out of } 5 \\
\text { opportunities ( } 80 \% \text { accuracy). }\end{array}$ & $\begin{array}{l}\text { 1. Achieved. Student was able to independently answer } \\
\text { wh- questions with } 80 \% \text { accuracy by the end of summer. } \\
\text { 2. Achieved. Student was able to identify story grammar } \\
\text { components with } 80 \% \text { by the end of the summer with } \\
\text { minimal cueing. } \\
\text { 3. Progressing. Student required assistance and } \\
\text { scaffolding to correctly sequence story events. }\end{array}$ \\
\hline $\begin{array}{l}\# 4 ; 2 \text { nd } \\
\text { grade }\end{array}$ & $\begin{array}{l}\text { Retell stories } \\
\text { using basic } \\
\text { story grammar, } \\
\text { sequencing } \\
\text { story, events by } \\
\text { and answering } \\
\text { who, what, } \\
\text { where, why and } \\
\text { how questions }\end{array}$ & $\begin{array}{l}\text { 1. Student will respond accurately } \\
\text { to who, what, and where questions } \\
\text { in small group or classroom in } 4 \text { of } \\
5 \text { opportunities ( } 80 \% \text { accuracy). } \\
\text { 2. Student will accurately describe } \\
4 \text { of } 5(80 \%) \text { story grammar } \\
\text { components with minimal clinician } \\
\text { cueing. } \\
\text { 3. Student will accurately sequence } \\
\text { parts of a story in } 4 \text { out of } 5 \\
\text { opportunities ( } 80 \% \text { accuracy). }\end{array}$ & $\begin{array}{l}\text { 1. Achieved. Student responded accurately to questions } \\
\text { with } 80 \% \text { accuracy. The student demonstrated adequate } \\
\text { understanding of the stories read to him, but did } \\
\text { demonstrate attention problems which negatively impacted } \\
\text { his ability to retell stories. } \\
\text { 2. Achieved. Student easily understood the components of } \\
\text { story grammar. } \\
\text { 3. Achieved with support. Student was able to accurately } \\
\text { sequence parts of a story, but required minimal cueing. }\end{array}$ \\
\hline
\end{tabular}


Table I-1. Continued

\begin{tabular}{|c|c|c|c|}
\hline $\begin{array}{c}\text { Student \# } \\
\text { and } \\
\text { Grade }\end{array}$ & $\begin{array}{c}\text { Intervention } \\
\text { Goals }\end{array}$ & Objectives & Outcomes \\
\hline $\begin{array}{l}\# 5 ; 4 \text { th } \\
\text { grade }\end{array}$ & $\begin{array}{l}\text { 1. Deliver oral } \\
\text { and or written } \\
\text { summaries of } \\
\text { books that } \\
\text { contain the main } \\
\text { ideas of the } \\
\text { events and the } \\
\text { most significant } \\
\text { details. } \\
\text { 2. Retell } \\
\text { classroom } \\
\text { reading } \\
\text { materials. }\end{array}$ & $\begin{array}{l}\text { 1. Student will be able to respond } \\
\text { appropriately and accurately to } \\
\text { questions regarding a given story } \\
\text { in } 4 \text { of } 5 \text { opportunities ( } 80 \% \\
\text { accuracy). } \\
\text { 2. Student will resolve ambiguities } \\
\text { about word and sentence meanings } \\
\text { when given a grade level story in } 4 \\
\text { of } 5 \text { opportunities ( } 80 \% \text { accuracy). }\end{array}$ & $\begin{array}{l}\text { 1. Progressing. Student was able to respond appropriately } \\
\text { to questions regarding story structure with } 100 \% \text { accuracy } \\
\text { with moderate cues (closed set of options and multiple } \\
\text { repetitions), however, accuracy decreased to } 60 \% \text { when } \\
\text { responding independently. It was observed that the student } \\
\text { had difficulty maintaining attention during sessions and } \\
\text { required frequent breaks to stay on task. } \\
\text { 2. Achieved. Student was able to complete with } 90 \% \\
\text { accuracy independently by the end of the summer. }\end{array}$ \\
\hline $\begin{array}{l}\# 6 ; 4 \text { th } \\
\text { grade }\end{array}$ & $\begin{array}{l}\text { 1. Deliver oral } \\
\text { and or written } \\
\text { summaries of } \\
\text { books that } \\
\text { contain the main } \\
\text { ideas and } \\
\text { important details } \\
\text { of the events. } \\
\text { 2. Retell, } \\
\text { paraphrase and } \\
\text { explain stories. }\end{array}$ & $\begin{array}{l}\text { 1. Student will accurately retell a } \\
\text { paragraph or short story, recalling } \\
\text { important details with } 80 \% \\
\text { accuracy. } \\
\text { 2. Student will resolve ambiguities } \\
\text { about word and sentence meanings } \\
\text { when given a grade level story in } \\
\text { (small group, classroom) in } 4 \text { of } 5 \\
\text { opportunities ( } 80 \% \text { accuracy). }\end{array}$ & $\begin{array}{l}\text { 1. Achieved. Student was able to respond appropriately to } \\
\text { questions regarding story structure with } 80 \% \text { accuracy } \\
\text { independently by the end of the summer using visual maps. } \\
\text { 2. Achieved. Student was able to complete with } 100 \% \\
\text { accuracy independently by the end of the summer. Using } \\
\text { context clues was notes as a strength for this student. }\end{array}$ \\
\hline
\end{tabular}


Table I-1. Continued

\begin{tabular}{|c|c|c|c|}
\hline $\begin{array}{c}\text { Student \# } \\
\text { and } \\
\text { Grade }\end{array}$ & $\begin{array}{c}\text { Intervention } \\
\text { Goals }\end{array}$ & Objectives & Outcomes \\
\hline $\begin{array}{l}\# 7 ; 5 \text { th } \\
\text { grade }\end{array}$ & $\begin{array}{l}\text { 1. Establish a } \\
\text { situation, plot, } \\
\text { point of view, } \\
\text { and setting with } \\
\text { descriptive } \\
\text { words and } \\
\text { phrases. } \\
2 . \text { Identify and } \\
\text { correctly use } \\
\text { verbs that are } \\
\text { often misused } \\
\text { (e.g. lie/lay, } \\
\text { sit/set, } \\
\text { rise/raise), } \\
\text { modifiers, and } \\
\text { pronouns. }\end{array}$ & $\begin{array}{l}\text { 1. Student will identify story } \\
\text { structure components from a } \\
\text { closed set of options ( } 100 \% \\
\text { accuracy). } \\
\text { 2. Student will identify story } \\
\text { structure elements with } 80 \% \\
\text { accuracy independently. } \\
\text { 3. Student will use correct word } \\
\text { endings in phrases/sentence when } \\
\text { responding to questions and stories } \\
\text { in } 4 \text { out of } 5 \text { opportunities ( } 80 \% \\
\text { accuracy). }\end{array}$ & $\begin{array}{l}\text { 1. Achieved. Student was able to read short stories and } \\
\text { determine story structure components when given a closed } \\
\text { set of } 3 \text { options. } \\
\text { 2. Achieved. Student was able to answer questions with } \\
80 \% \text { accuracy independently. Spelling was noted to be } \\
\text { difficult during written tasks. } \\
\text { 3. Achieved. By the end of the summer, the student was } \\
\text { able to complete questions, as well as produce sentences } \\
\text { using the correct verb tense. }\end{array}$ \\
\hline $\begin{array}{l}\# 8 ; 5 \text { th } \\
\text { grade }\end{array}$ & $\begin{array}{l}\text { 1. Establish a } \\
\text { situation, plot, } \\
\text { point of view, } \\
\text { and setting with } \\
\text { descriptive } \\
\text { words and } \\
\text { phrases. }\end{array}$ & $\begin{array}{l}\text { 1. Student will identify story } \\
\text { structure components from a } \\
\text { closed set of options. } \\
\text { 2. Student will identify important } \\
\text { details (character, setting, } \\
\text { resolution, conflict, emotion) } \\
\text { about a short story with } 80 \% \\
\text { accuracy independently. }\end{array}$ & $\begin{array}{l}\text { 1. Achieved. By the end of the summer, student } \# 8 \text { was } \\
\text { able to read short stories and determine story structure } \\
\text { components when given a closed set of } 3 \text { options. } \\
\text { 2. Progressing. Student was able to answer questions with } \\
80 \% \text { accuracy from open sets with visual cues both in } \\
\text { written and verbal format, but not independently. The } \\
\text { student tended to have slightly better comprehension if the } \\
\text { story was read to him. }\end{array}$ \\
\hline
\end{tabular}




\section{VITA}

Lisa Bowers is a certified speech-language pathologist with seven years of experience working as a school-based SLP with students from culturally and linguistically diverse backgrounds. With acceptance of this dissertation, she will hold a Ph.D. degree from the University of Tennessee Health Science Center Speech and Hearing Science Program. Her research focuses on the language and literacy abilities of elementary and middle school students. She will begin working at the University of Arkansas as an Assistant Professor in August 2012. 